\title{
Conservation, Management and Expansion of Protected and Non-Protected Tropical Forest Remnants Through Population Density Estimation, Ecology and Natural History of Top Predators; Case Studies of Birds of Prey (Spizaetus taxon)
}

\author{
M. Canuto, G. Zorzin, E. P. M. Carvalho-Filho, C.E.A. Carvalho, \\ G.D.M. Carvalho and C.E.R.T Benfica \\ S.O.S. Falconiformes, \\ Centro de Pesquisa Para a Conservação das Aves de Rapina Neotropicais,
}

\section{Introduction}

Among the Accipitridae family, the genus Spizaetus is included in the group of the Booted Eagles (Griffiths et al., 2007; Haring et al., 2007), which according to old taxonomic classifications, was the most diverse, with 22 species that inhabited the tropical forests of the New and the Old World (Brown and Amadon 1968, del Hoyo et al. 1994, Ferguson-Lees and Christie 2001). Most specimens of this taxon are medium sized $(1,100-1,600 \mathrm{~g})$, but there are some exceptions which are smaller (S.nanus, 510-610g) or larger (S.nipalensis, 2,500-3,500g) (del Hoyo et al. 1994, Ferguson-Lees and Christie 2001). The first description of the genus Spizaetus was introduced by Vieillot in 1816, when he described the taxon S. ornatus (Haring et al. 2007). This species, along with S.tyrannus, is found in the neotropical region, and both are divided into two subspecies (Brown and Amadon 1968, Ferguson-Lees and Christie 2001). Only one species occurs in the African continent, while most of the species of this genus are distributed throughout Southeast Asia (Haring et al. 2007). However, the grouping of this genus based on comparisons of the external morphology and feather patterns, according to traditional taxonomy, was refuted by a recent classification based on genetic studies (Haring et al. 2007). These authors consider the genus as paraphyletic, segregating the taxon into three distinct groups (Neotropical, African and Asian): while the neotropical representatives maintained the genus name due to Vieillot's first classification (Spizaetus ornatus, 1816); the African representative was inserted in the genus Aquila and the Asian ones renamed as Nisaetus.

Haring et al. (2007) and Griffiths et al. (2007) also evaluated the phylogenetic relationship of the genus with two other neotropical taxons, Spizastur melanoleucus and Oroaetus isidori. Although indicating that the archetypes from South America would not form a 
monophyletic clade, the authors adopted a more conservative classification, adding these two species to the genus Spizaetus (Helbig et al. 2005, Haring et al. 2007, Griffiths et al. 2007), which is the same taxonomy adopted by the AOU (American Ornithologist's Union). Thus, the genus would be represented by S. isidori, with distribution restricted to the Andes strip extending from Venezuela to the far north of Argentina; S.tyrannus, S.ornatus and S.melanoleucus, which are much more widely distributed through South America, including almost all of Brazil (Sick 1997) and part of Central America (Blake 1977, Ferguson-Lees and Christie 2001).

Even with phylogenetic uncertainties, these species have in common many ecological characteristics which are important in terms of biodiversity conservation. They demand large areas of well conserved forests (Jullien and Thiollay 1996, Thiollay 1989a,b, 2007, Bierregard 1998, Canuto 2009), which characterizes them as "umbrella" species for their environment (Newton 1979), when populations from other species, with smaller home ranges are preserved in locations that support viable populations of these predators (Sergio et al. 2006). These birds are also paramount for ecological balance, regulating populations of their eventual prey (Newton 1979, Bierregard 1998, Watson 1998).

The loss of top predators, such as these hawk-eagles, may entail a large increase in mesopredator release, affecting the populations of their prey and may even lead them to extinction (Soulé et al. 1988, Terborgh 1992). Like other raptors, they are also good indicators of environmental change (Newton 1979, Thiollay 2007, Seavy and Apodaca 2002, Carrascal et al. 2008a, b, Carvalho and Marini 2007), as they are sensitive to anthropic disturbances, including hunting and selective logging (Thiollay 1989a, 2007; Stotz et al. 1996).

Deforestation and fragmentation of tropical forests are this species' main threats (Bierregard 1998, Bildstein et al. 1998, Thiollay 2007, IUCN 2010). Considering the rates of tropical deforestation in the last few decades (Whitmore 1997), some taxons have become especially vulnerable to local extinction.

The neotropical species, S. melanoleucus, S. ornatus and S. tyrannus, are much more widely distributed throughout all of South America and parts of Central America (Blake 1977, Ferguson-Lees and Christie 2001). These species have large populations in the Hylean Amazon, thus contributing to the fact that they were not considered endangered in Brazil or worldwide (Machado et al. 2008, IUCN 2010). However, they have become extremely rare outside the Amazon domain (Sick and Teixeira 1979, Sick 1997“, Drummond et al. 2008). The regional decrease of these taxons, due to the reduction of forest environments in Southeastern Brazil, is made clear with their presence in state lists of endangered species in Southeastern and Southern regions of Brazil (Bergallo et al. 2000, Silveira et al. 2009, Fontana et al. 2003, Mikich and Bérnilis 2004, Simon 2007). As well as the deforestation of the Atlantic rainforest "(SOS Mata Altântica e INPE 2010), which is identified as these species' biggest threat, trapping and hunting are secondary contributors to the decrease of their population status (Albuquerque 1995, Machado et al. 1998, Ribon et al. 2003).

Despite recent records in many localities of the Atlantic domain and in other areas of the Cerrado (Kirwan et al. 2001, Azevedo et al. 2003, Manõsa et al. 2003, Ribon et al. 2003, Carlos and Girão 2006, Joenck 2006, Olmos et al. 2006, Roda and Pereira 2006, Zorzin et al. 2006, Dias and Rodrigues 2008, Carvalho Filho et al. 2009, Faria et al. 2009, Salvador-Jr. and Silva 
2009, Salvador-Jr. et al. 2011), there is no evidence about the reproduction of these species in most areas where they were found. Also, there is a complete lack of substantial data on their local density as well.

The best efforts of data collection on the biology and ecology of these taxons were concentrated in areas of continuous forests in Guatemala (Flatten 1990, Julio et al. 1991, Sixto, 1992, Montenegro 1992), the French Guyana (Thiollay 1985, 1989a,b Jullien and Thiollay 1996, 2007) and in large forest fragments in Brazil (Canuto 2009, Manosa et al. 2002, 2003). Other works regarding territoriality and estimates of genus density usually include collection of complementary data with the use of radio telemetry equipment (Manõsa and Pedrochi 1997, van Balen et al. 2001 and Gjersshaug et al. 2004).

In some studies, such as Thiollay (1989a,b), Preulethner and Gamauf (1998), Whitacre et al. (1992a) van Balen et al. (2001) and Canuto (2009), the authors estimated the density of pairs and territoriality by direct observation of pairs and individuals performing flight circuits and aerial displays. Generally speaking, population census in preserved habitats of many species of Accipitriformes - especially those that are more selective such as the individuals of the Spizaetus genus - enable the prediction of the distribution of a specific population in a mosaic of modified environments. This is how the regional or local status of the species may be evaluated (Thiollay 2007). However, the lack of specific census that aim to evaluate more precisely the density of these species in altered environments, does not permit further inference on their local state of conservation in most of their current areas of occurrence. Therefore, there is less information available on the dynamics of these species' populations in fragmented areas, such as the Southeast and Center-West regions of Brazil.

In the current chapter we describe the results of five studies conducted in the country by analyzing the incidence of specimens of the genus Spizaetus in areas with different fragmentation histories and considering the different population and reproductive ecological aspects of these taxons collected at each locality. By analyzing each case study we promote a reflection on the perspectives of local and punctual conservation of these species, according to their ecological requirements. Thus, we used these species as "flags" to point out the problems involving conservation of top predators, which present small density but demand a large area, in fragmented and continuous areas.

\section{Methods and study areas}

For the study sites we present the different localities, including different regions of the Cerrado and Atlantic Rainforest and their respective transition areas where different data collections occurred. Later, these results are discussed in a regional context according to previous results by the authors obtained from the Amazon biome and a second tropical region (Central America).

In each case study specific methods were employed for census, mapping and monitoring of these species according to Whitacre and Turley (1990), Thiollay (1989), Bibby et al. (2000), Manõsa et al. (2003), Canuto (2009) and Granzinelli and Motta Junior (2010). These taxons require an ample and specific sample effort, as they are highly territorial birds that occur in low density and occupy extensive territories. However, these methods were applied differently according to the focus of each study by different authors, thus involving different 
sampling parameters according to the environment, conditions of region preservation and the logistics involved. The methods are described below:

i. Observations through point counts: This method consists of recording species from a fixed observation point during a pre-established period, over a large time-scale, involving different seasons. It was used to evaluate the density, frequency of occurrence and incidence of pairs and individuals of the focus species in the sampling areas. For the density estimates, we used a fixed observation radius, and for calculating the frequency of occurrence, all individuals accurately identified within the range of observation were considered. Each point should allow an ample field of vision, and observations were made with the aid of binoculars 10x42 Nikon and a spotting scope (20-60x), during a specific period of time that varied between 4 and 5 hours, beginning first hours of the day.

ii. Data collection by routes: This technique was used to estimate the frequency of occurrence of the species, as well as to identify new areas of use and nesting. Surveys were conducted in roads, slowly driving a vehicle, as well as in rivers with a motorboat or boat, or on foot in paths in the surrounding and interior areas of the remaining forests.

iii. Spot mapping: According to Bibby et al. (2000) and Sutherland (2004), this technique consists of mapping the movements of the individuals from observations made from fixed points, including use of climbing techiniques for point counts within the forest canopy. All the movements and routes of individuals of these species were recorded, followed by the representation of these movements and activities on a digital map of the area. After the identification of active territories or breeding sites, various observation points were distributed in the area defended by the resident individuals. The more repetitions performed within these territories, the more accurate are the estimates of displacement, therefore confirming which sites were occupied or defended. The birds observed were usually identified by the imperfections in the flight feathers (remiges and rectrices) and patterns of plumage (adult, sub-adults or youngsters). Other points in the surrounding area of the occupied territories and adjacent ones were scouted with the objective of verifying the overlap of territories or unoccupied areas.

As previously described, differences occurred in the use of these methods according to the intrinsic characteristics of each area, logistics, and the objectives of the following studies:

- Case Study 1 "Density of the representatives of the genus Spizaetus in remaining continuous Atlantic Rainforest in the east of the state of Minas Gerais, Brazil"

- Case Study 2 "Estimates of territoriality, incidence of pairs and reproduction sites of Spizaetus tyrannus in the south of the state of Minas Gerais, Brazil"

- Case Study 3 "Estimates of territoriality, incidence of pairs and reproduction sites of Spizaetus melanoleucus in Atlantic Rainforest fragmented areas in the east of the state of Minas Gerais"

- Case Study 4 "Density and territoriality of Spizaetus ornatus in the Araguari river valley, Triângulo Mineiro Region"

- Case Study 5 "The effects of fragmentation of the Atlantic Rainforest on the richness and abundance of Accipitriformes in the region of Viçosa, Minas Gerais" 


\section{Results}

\subsection{Case study 1}

"Density of the representatives of the genus Spizaetus in remaining continuous Atlantic Rainforest in the east of the state of Minas Gerais, Brazil"

The Doce River State Park (Parque Estadual Rio Doce - PERD) is the largest Atlantic Rainforest park in Minas Gerais, with an area of 35.976,43 ha, and $120 \mathrm{~km}$ in perimeter. The reserve is located in the Doce River Valley, eastern part of the state, between the $42 \mathrm{o} 38^{\prime} \mathrm{W}$ and $48 \mathrm{o} 28^{\prime} \mathrm{W}$ meridians and the 19o 45'S and 19o 30'S parallels, with an altitude varying between 230 and $515 \mathrm{~m}$. The reserve has as important landmarks, the limits of the Doce and Piracicaba rivers, to the east and northeast respectively (Hirsch 2003a).

The PERD vegetation belongs to the lower montane Atlantic Rainforest formation (Rizzini 1979) and is composed by a mosaic of primary and secondary forests (Ferreira and Marques 1998) classified as Semi Deciduous Forest (Viana 2001). The reserve has a freshwater system of 38 to 44 lagoons which amounts to 3,529.7 ha (approximately $6 \%$ of the total area).

For the Spizaetus density estimates (Table 1), the spot mapping method was used registering the routes of the three species of this genus. The results were obtained according to the occupation of the species within the 12 sampling plots, a total of 21,400 hectares. These records attested to the presence of pairs in reproductive activity or that were actively nesting. It was collected 126 samples between 2006 and 2009, concentrated between the months of July and January. There were 1 to 4 fixed observation points in each plot, inside the reserve and border. These points occurred on the canopy of emerging trees $(n=23 / 83$ sample repetitions), with the use of climbing techniques, and also in open areas throughout the border of the reserve ( $\mathrm{N}=10$ / 43 repetitions). All 33 points had a mean distance of $831 \mathrm{~m}$ $( \pm 514 \mathrm{~m})$, the minimum distance being $100 \mathrm{~m}$ and the maximum $2 \mathrm{~km}$ between the points within a plot. These sets of fixed points were sampled from 07:30 to 12:00. The mean distance between plots, each one with $1-4$ point counts, was $5.3 \mathrm{~km}( \pm 2.2 \mathrm{~km})$, and varied between 2.2 and $9 \mathrm{~km}$. All points had a wide viewing angle, between $120^{\circ}$ to $360^{\circ}$, mean $260^{\circ}$ $( \pm 64)$, which enabled an evaluation of the occupation or defense of the plots by aerial and territorial displaying individuals. This was determined by the recordings of pairs engaged in reproductive behavior or in defense of the plots, thus generating a density estimate of the minimum number of pairs inside the reserve's boundaries. The plot was considered occupied when a minimum of two records on pairs took place. This estimate does not include subordinate birds, immatures, wandering individuals with no defined territory, and individuals not reproductively active, as predicted by Meunier's "reservation population" (1960). Methods i, ii and iii (see methods and study area sections) were applied during the study, with a total of 567 hours of direct observation.

For the Spizaetus tyrannus species, records of territories occupied by pairs were inexistent, so clear patterns of territoriality were not obtained. However, the species' incidence in the plots is still considered because of the random records of individuals presenting the territorial behavior.

A minimum number (Table 1) of 4 pairs of the Ornate Hawk-eagle (S. ornatus) in 21,400 ha, and 6.7 pairs in 36,000 hectares of the PERD was estimated, with a density of approximately 1 pair per 5,373 hectares. For the Black-and-white Hawk-eagle (S. melanoleucus) five plots 
had records of matched pairs in 21,400 ha (12 sampling plots), generating a minimum estimate of 5 pairs in 21,400 ha, and 8.4 pairs of the species in 36,000 ha, with an approximate density of 1 pair per 4,285 hectares. For the Black Hawk-eagle (S. tyrannus), 4 plots had individuals recorded, being those characterized by territorial defense behavior, as soaring flights along with vocalizations specific to the species. This generated an estimate of a minimum of 4 pairs in 21,400 hectares, and 6.7 pairs in 36,000 hectares of the PERD, with a density of approximately 1 pair per 5,373 hectares, similar to the first species. Therefore, $S$. melanoleucus was considered the most abundant species in this Atlantic Rainforest reserve of semideciduous seasonal lowland of 36,000 hectares, more than 40 lake formations, and three watersheds, as well as the Doce River, along the eastern limits of the reserve, and the Piracicaba River, along the northern limits.

\subsection{Case study 2}

"Estimates of territoriality, incidence of pairs and reproduction sites of Spizaetus tyrannus in the south of the state of Minas Gerais, Brazil"

For this study, three sites were evaluated (Table 1), two located between the municipalities of Ibertioga, Juiz de Fora and Itutinga (Study Sites 1 and 2), and one in the municipality of Capela Nova (Study Site 3), all of which are in the state of Minas Gerais (200 49'S - 210 34'S $\left.44^{0} 13 \mathrm{~W} 43^{\circ} 24^{\prime} \mathrm{W}\right)$. The region has remnants of Atlantic Rainforest, which are concentrated on the slopes and hilltops. It also has tracts of Cerrado vegetation, with modifications due to agriculture. The region's altitude varies between 780 to 1,200 meters ASL. It is characterized by seasonal, semi-deciduous forests associated to Cerrado vegetation, with field areas with anthropogenic interference and areas of aquatic environment. The municipality of Capela Nova is characterized by a mosaic of forest fragments on hill tops and depressions, pasture areas, rural properties and river valleys, as well as rocky formations on forested slopes.

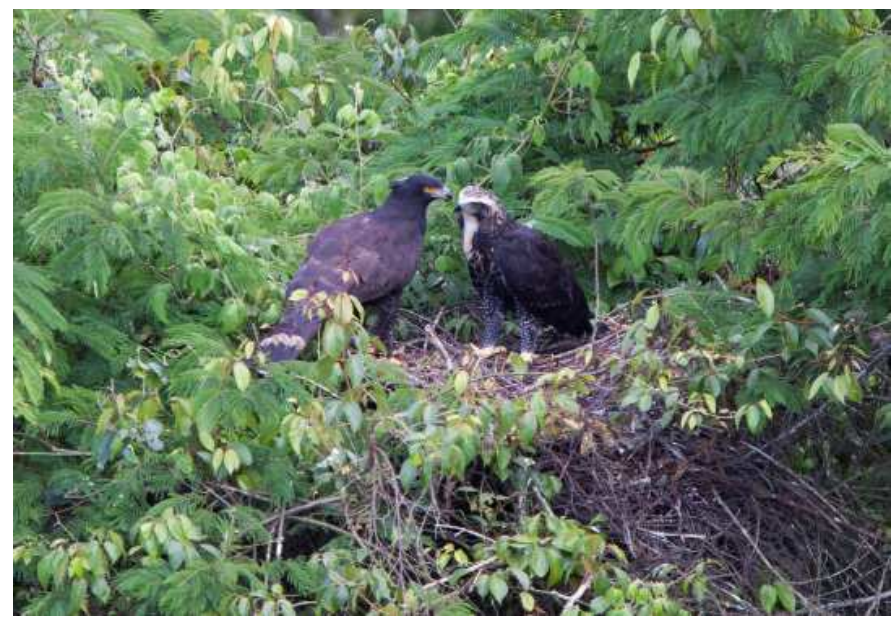

Photo 1. Black hawk-eagle nest with young. Photo credit: Eduardo Pio Carvalho

The three sites are located to the south of the state capital, Belo Horizonte, and are near or part of the Serra da Mantiqueira mountain chain. 
For case study 2, the methods included direct observation of the species using fixed points of variable radius in accordance with Whitacre and Turley (1990), Whitacre et al. (1992a) and Canuto (2009), in landscape vantage points such as hill crests (sites 1 and 2). An observation platform was also used in a tree canopy (site 3), with ascension techniques for the monitoring of a nest (Photo 1). To avoid influences on the individual's behavior, a blind tent was used, in such a way that the nesting pair could not see the observers most of the time. The different areas were monitored by at least quarterly visits for collecting data on the reproductive biology, monitoring of the reproductive sites or active nesting and, consequently, evaluating the patterns of territoriality. In the nesting area monthly visits were carried out.

In sites 1 and 2, two pairs were monitored, $23 \mathrm{~km}$ apart, through methods i, ii, and iii. Both pairs presented display or territorial defense behavior in both areas in the years of 2007 and 2008. In both cases the forests were considered of late secondary succession and had distinct strata. Movements and territoriality patterns were characterized in displacements of up to $1.6 \mathrm{~km}$. On one occasion, 3 individuals were sighted in one of the areas, which could have been a pair and a youngster. Both areas are characterized by forested slopes or hilltops on rugged terrain.

In site 3 a nest was identified (Charles Moreira, personal communication) inside a ravine in a small drainage basin at an altitude of 776 meters, in a secondary fragment in intermediate stage of regeneration. Starting at this point, specimens used a route along the ravine valley to exit and enter the nest as well as other points. The patch is approximately 175 hectares in size and is inserted in a mosaic of larger and smaller forest patches in a region of river valleys with some local agropastoral pressure. The nest was on an Angico tree (Anadenanthera sp.) at a height lower than 20 meters. The tree is located 400 meters from the Piranga River and 700 meters from a stream. Its circumference at breast height $(\mathrm{CBH})$ is $1.40 \mathrm{~m}$.

\subsection{Case study 3}

"Estimates of territoriality, incidence of pairs and reproduction sites of Spizaetus melanoleucus in Atlantic Rainforest fragmented areas in the east of the state of Minas Gerais".

Eastern Minas Gerais, precisely the middle Doce river basin, is located between parallels $18^{\circ} 45^{\prime}$ and $21^{\circ} 15^{\prime} \mathrm{S}$ and meridians $39^{\circ} 55^{\prime}$ and $43^{\circ} 45^{\prime} \mathrm{W}$, comprising a drainage area of about 83,400 sq. $\mathrm{km}$, of which $86 \%$ belongs to the state of Minas Gerais and the remaining area to Espírito Santo. In its southern border is the Paranaíba do Sul river basin, and in the west the São Francisco river basin, as well as some of the Grande river. In the north, it borders the Jequitinhonha and Mucuri river basins and in the northeast the São Mateus river basin. The average annual precipitation varies from 1,500 $\mathrm{mm}$, in the springs located in the Mantiqueira and Espinhaço mountain ranges, to $900 \mathrm{~mm}$, in the region of the city of Aimorés, increasing towards the coast.

The study areas were the Doce River State Park and surroundings (Case study 1), the Private Reserve of the Feliciano Miguel Abdala Natural Patrimony in Caratinga, the municipalities of São José do Mantimento and São Pedro do Suaçuí, and a district near the city of Governador Valadares, Baguari, all of which are in the middle Doce river watershed, in the state of Minas Gerais. In these areas, the presence of active or inactive nests of $S$. 
melanoleucus, or incident pair, were documented. Patterns of territoriality and distance estimates (Table 1) were obtained according to the spot mapping method. Also, data was collected on the reproductive biology of the species. Methods i, ii and iii were used.

In the first area, located in the Doce River State Park and surroundings (see Case study 1), two nests were found and tracked. One inside the reserve (Canuto 2008b), located on a pink Jequitiba tree (Cairina legalis - $\mathrm{CBH} 291 \mathrm{~cm}$ ) at a height of 37 meters and at a distance of about 800 meters from the border. It was located at the base of the hill among different ravines or drainage systems, near a ridge of approximately 250 meters in altitude and about 770 meters away from the Turvo stream.

A second nest (Fabiano R. de Melo, personal communication) was studied around the same location in a hillside forest patch in a dry valley of approximately 1,700 hectares, which is located $2 \mathrm{~km}$ away from the Mumbaça stream, border of the PERD. This nest was $13 \mathrm{~km}$ away from the first nest. The patch was isolated from the reserve by Eucalyptus crops and open areas. The nest was located on an Arara Nut Tree (Joannesia sp.) of approximately 35 meters in height. Displacements up to $3.5 \mathrm{~km}$ were mapped in both areas.

In the second area, a nest which was already known (Fernanada Tabacow, personal communication) was visited and found to be active (Photo 2) in the municipality of Caratinga, which has protected semidecidual forests of 1,000 hectares in size. The nest was on a Zeyheria cf. tuberculosa of 51 meters in height and CBH 2.7 meters. This nesting tree is located at an altitude of 700 meters, also along forested ridges and valley depressions. The location of the nest provides a broad view of the depression. The tree is $1.7 \mathrm{~km}$ away from the Manhuaçu river. Displacements of up to $1.5 \mathrm{~km}$ were mapped. This area is located at a distance of $75 \mathrm{~km}$ from the first two nests mentioned.

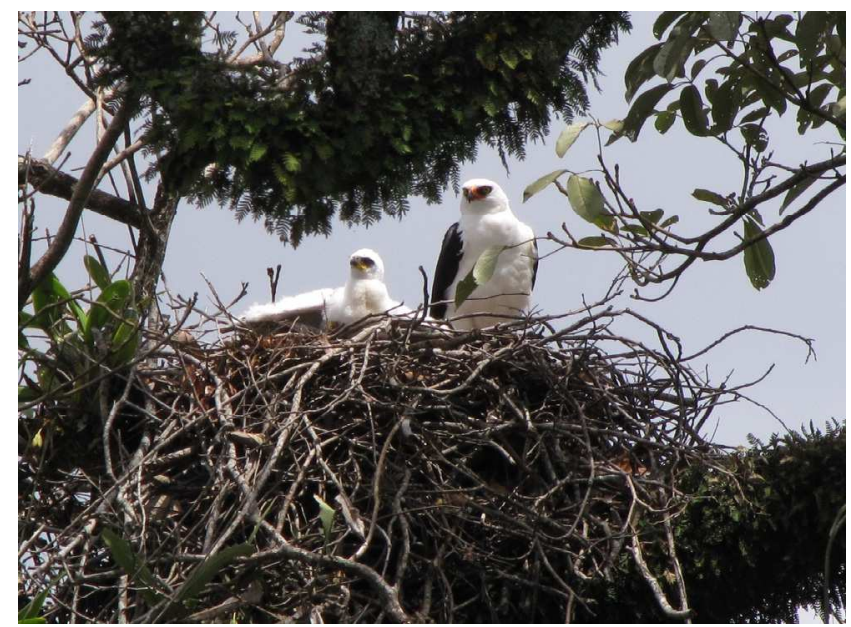

Photo 2. Black-and-white Hawk-eagle nest with young. Photo credit: Marcus Canuto

In the third area, near the city of Governador Valadares, the nest was on an emerging tree ( $\geq 30$ meters) located at the crest of a hill, 280 meters in altitude, near many slopes and depressions, and at a distance of $1.73 \mathrm{~km}$ from the Doce river. The tree was beside a small 
portion of native vegetation on top of the hill, even though the environment is dominated by Eucalyptus sp. plantations (approximately $>60 \%$ ). The tree was not measured. The species had been previously recorded by different observers on an island with mature trees $(>30 \mathrm{~m})$, in a nearby area, $8 \mathrm{~km}$ away from the nest, which had not yet been discovered at the time. After the island was flooded by a hydroelectric company, the pair was recorded on a monthly basis around the nest area for a period of 8 months before evidence of nesting was confirmed. Displacements of up to $4 \mathrm{~km}$ were mapped. The area used by the specimens throughout the months amounts to 1,293 hectares of Eucalyptus, streams, native vegetations and environments inhabited by man.

Another nest of the same species was found in 2001 (Marcelo Vasconcelos personal communication) in the northern region of the Doce river basin, in the municipality of São Pedro do Suaçuí, a more dry and arid region. This nest was located 900 meters away from the margins of the Suaçuí Grande river. The area was revisited in 2010, where an individual was recorded $7.5 \mathrm{~km}$ away from the previous nesting tree; however, the structure of twigs was no longer present. At the same location, an adult individual of the species S. tyrannus was recorded. This area is located at approximately $95 \mathrm{~km}$ northwest of the Governador Valadares nest.

To the east of the Doce river basin, a pair was sighted in São José do Mantimento, showing courtship or territorial defense behaviors, as observed by the vocal emissions and diving or dashing against each other over the course of two days. This was recorded in a 966 hectares forest patch that is located at the margins of the José Pedro river. This site is approximately $30 \mathrm{~km}$ southeast of the Caratinga nest.

\subsection{Case study 4}

"Density and territoriality of Spizaetus ornatus in the Araguari river valley, Triângulo Mineiro Region"

The Araguari river source is located in the Serra da Canastra national park in the municipality of São Roque de Minas and covers an area of approximately 2185 ha, with an extension of $475 \mathrm{~km}$. The vegetation above the river gorge, such as the remnants of the Cerrado latu sensu, were heavily modified due to the creation of extensive pastures and the modernization of agricultural techniques of edaphic correction, geared towards the production and exporting of grains (Ferreria et al. 2005). Enclaves of Atlantic Rainforest are concentrated along the valley, where the rugged topography has limited the advance of agropastoral activities, with some patches remaining somewhat isolated on steeper slopes. However, the implementation of the hydroelectric power plants of Nova Ponte, Miranda and Amador Aguiar I and II eradicated the riparian vegetation and contributed to the disfigurement of the remaining vegetation physiognomy, such as the deciduous forests.

Estimates of vegetation coverage and the use of the soil in the valley's area point to few areas occupied by deciduous forests, riparian vegetation and savannahs (19\%), all in secondary stages, with the largest part of the area used for pastures $(50 \%)$ and other annual cultures (31\%) (Rosa et al. 2006). The region's climate is of the Aw type, according to Köppen's classification, which is characterized by a dry period, from the months of April to September, and a humid period between the months of October to March (Rosa et al. 2006). 
The valley's altitude varies between 500 and $950 \mathrm{~m}$, and the slope percentage varies between 20 and $80 \%$.

To protect the few remaining areas of native vegetation, the Pau Furado State Park was created, located between the municipalities of Araguari and Uberlândia, and established as a compensatory measure for the Amador Aguiar I and Amador Aguiar II hydroelectric power plants. The area includes 2.200 ha, covered by remnant forests in different stages of succession. It's the first conservation unit of this category located in the Triângulo Mineiro Region, and one of the areas in the state that has been most affected by deforestation throughout the years.

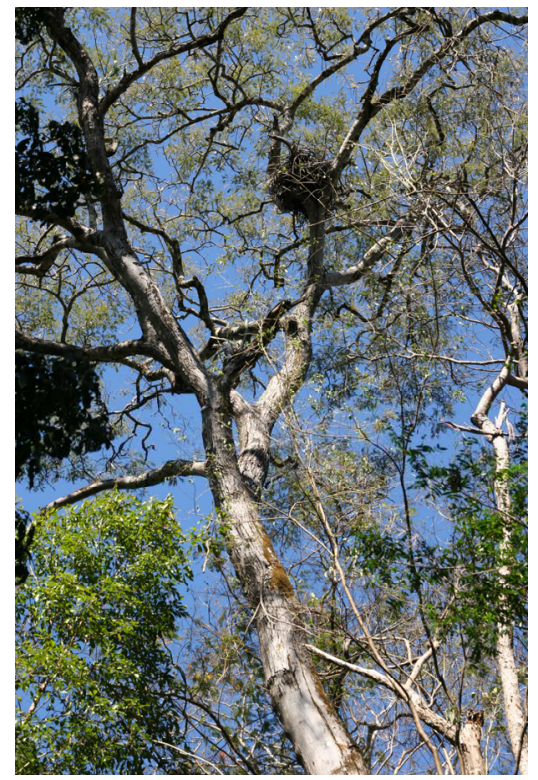

Photo 3. Ornate Hawk-eagle nest Photo credit: Eduardo Pio Carvalho

After the year 2005, when a few sporadic contacts with S. ornatus and S. tyrannus occurred in the Araguari river valley, another two years of efforts were carried out with the objective of finding the reproductive sites of these species and mapping the distribution of these taxons in an area of approximately $700 \mathrm{sq} . \mathrm{km}$, including part of the valley and adjacent areas.

Some contacts occurred randomly during field work done in the site in 2005, while other records were obtained during surveys carried out in the area in the following two years, when survey methods by transit and fixed point observations and spot mapping were used. Several recordings occurred during car trips and motorboat trips on the Araguari river. Many observations were randomly performed throughout the valley, with an average time of 4 hours of observation ( $08 \mathrm{am}-12 \mathrm{pm})$. The selected sites had a field view of at least 150 degrees and were located on hilltops with an ample view of the valley. Through direct observations, the routes of individuals or matched pairs were mapped when it was possible to distinguish the individuals by imperfections in their flight feathers and describe distinct territories. Additional observations were performed after the identification of the occupied 
areas to better map the individuals. Other points were established among the identified territories in order to identify possible overlapping territories or unoccupied areas.

Through mapping, pairs of S. ornatus were recorded in an area of 70.000 ha. Their activities were concentrated around the two largest remaining forest areas in the region, of approximately $1.000 \mathrm{ha}$, and a distance of $21 \mathrm{~km}$ between them (Table 1). In one of these areas we found an active nest in 2006. The area is characterized by secondary vegetation with some patches in initial stages and others more advanced, and with a few emerging trees, including patches of Cerrado. The nest was built on a Copaiba (Copaifera langsdorffii) with approximately $23 \mathrm{~m}$ in height and a $\mathrm{CBH}$ of $2.07 \mathrm{~m}$. The tree was located $1.9 \mathrm{~km}$ from the Araguari river, $40 \mathrm{~m}$ from a small stream and $27 \mathrm{~m}$ from a pasture in the valley. During the reproduction period we observed displacements of at least $4.5 \mathrm{~km}$ from the nest. In the other forest fragment no nests were found; however, a pair was observed performing courting flights and vocalizations. The records of $S$. tyrannus in the valley can be summarized by two isolated contacts with adult individuals.

\subsection{Case study 5}

"The effects of fragmentation of the Atlantic Rainforest on the richness and abundance of Accipitriformes in the region of Viçosa, Minas Gerais"

This effort was focused between the municipalities of Viçosa, Paula Cândido and Cajuri, in the mesoregion of the "Zona da Mata" in Minas Gerais, which covers an extension of 100 sq. $\mathrm{km}$, between the parallels $20^{\circ} 42^{\prime} 30^{\prime \prime}$ and $20^{\circ} 50^{\prime} 00^{\prime \prime} \mathrm{S}$ and $42^{\circ} 48^{\prime} 45^{\prime \prime}$ and $42^{\circ} 56^{\prime} 15^{\prime \prime} \mathrm{W}$. The original vegetation is part of the Sub-montane Semideciduous Forest formation (OliveiraFilho and Fontes 2000), characterized by the seasonal loss of 20 to $50 \%$ of tree leaves, and by an altitude of 300 to $700 \mathrm{~m}$.

In 1817, the region was covered by primary forests, with small secondary patches due to subsistence farming of indigenous peoples and isolated farming activities (Ribon et al. 2003). The effective occupation of the Forest Zone began with the introduction of coffee plantations in the Parnaíba river basin in Minas Gerais, around mid-19th century, with the occurrence of widespread destruction and fragmentation of the landscape, caused by the creation of extensive plantations (Valverde 1958). Following the coffee plantations, cattle ranching expanded as the crop became unproductive, and the plantations became pasture grass (Melinisminutiflora) (Resende and Resende 1996).

The coffee cycle ended in the first decades of the 20th century, which probably led to the regeneration of various forest fragments from old abandoned crops (Ribon et al. 2003). Thus, many fragments in the region of Viçosa have between 20 and 60 years of regeneration (Ribon et al., 2003). According to the latest expectations, the area's forest cover reaches $20 \%$ (Zorzin 2011), with fragments concentrated on slopes and hilltops, rarely on lowlands and caves, and practically none with watercourses in their interior (Ribon 1998). Most of these remaining fragments are no larger than 50ha and few cover an area superior to 300ha. Even with the regeneration of many fragments, they are still exposed to distinct anthropic disturbances, such as fire, invasion by domestic cattle and selective logging (Ribon et al. 2003, Silva Júnior et al. 2004), while many also have their area reduced by the implantation of small cultures (personal communication). 
Currently, the landscape matrix has different uses, such as coffee plantations of various extensions, other crops to a lesser extent (such as corn, rice and beans), small eucalyptus (Eucalyptus spp.) plantations, pastures and secondary forests (Ribon et al. 2003).

For the recording of medium and large sized Accipitriformes, we used fixed observation points and trajectory surveys. The selection of points was based on a PRISM/ALOS satellite image with a $2.5 \mathrm{~m}$ resolution. We selected 25 points that had distances longer than $800 \mathrm{~m}$ from other points and offered a different field view from these. The shortest distance between selected points was $820 \mathrm{~m}$ and the average minimum distance was $1.714 \mathrm{~km}$.

These points were selected during two seasons, according to the Brazilian species' reproductive cycle (Sick 1997, Carvalho-Filho et al. 1998, 2005, 2006, 2009, Ferguson-Lees and Christie 2001, Zorzin et al. 2004, Azevedo et al. 2006, Canuto 2008b, Canuto2009). The first sampling was concentrated between December of 2009 and February of 2010, which corresponds to the end of the reproductive period, when it was possible to record the dispersal of the youngsters; the second period occurred between the months of August and November of 2010, which includes reproductive activity such as pairing of mates, courting flights and incubation.

Observations at the points occurred for five hour periods, from 7 am to $12 \mathrm{pm}$. The transit observations were conducted in the interior and outskirts of the region's 35 remaining forest fragments.

After reviewing Ribon et al (2003), Zorzin (2011) attested to the local extinction of S.ornatus and S.melanoleucus. These species were previously considered as critically endangered in the region by Ribon et al. (2003). The only species observed by Zorzin (2011) was S.tyrannus, when a minimum number of 3 adults, identified by imperfections in the remigi, were estimated in an area of 10,000ha (Table 1). One of these birds was recorded at points distanced by $10 \mathrm{~km}$. Zorzin (2011) also analyzed the landscape's influence, in different scales, on the abundance of $S$. tyrannus in the region, analyzing the presence of this species in 35 fragments. This author found significant correlations $(p<0.01)$ between the species abundance and the sizes of the remaining forest areas. Using buffers of 500, 1000, 1500 and $2000 \mathrm{~m}$, this author also found significant correlations between the abundance of the taxon and the percentage of forest cover around the fragments, the amount of nuclear area and the average size of the remaining fragments of the landscape. On the broadest scale adopted, the $2000 \mathrm{~m}$ radius, the abundance of the species showed significant negative correlation $(\mathrm{p}<0.05)$ to the average isolation of the surrounding fragments.

\section{Discussion}

For the case studies conducted in the Atlantic Rainforest and transition areas, according to territoriality estimates for the genus corresponding to Table 1, we were able to evaluate the incidence of the group in forest patches of at least 179 ha for S. tyrannus nests, and of 8401.000 hectares for the incidence of pairs and nests of S. melanoleucus and S. ornatus in areas with intense history of fragmentation. It is clear that their protection should be a priority, as well as of small, medium and large Atlantic Rainforest fragments, to create wildlife corridors which guarantee the existence of refuges and source or dispersal areas (see Laurance et al. 1997). However, most of what is left of the Atlantic Rainforest is found in 
small forest fragments <100ha (Ranta et al. 1998; Ribeiro et al. 2009) which are isolated from each other and composed of portions of secondary forests in recent or medium regeneration stages (Viana et al. 1997, Metzger 2000, Metzger et al. 2009 In Ribeiro et al. 2009). Therefore, the pressure caused by deforestation of the genus in the Atlantic Rainforest is still present, whereas the process or history of deforestation in the biome is prior to the $20^{\text {th }}$ century.

\begin{tabular}{|c|c|c|c|c|}
\hline \multicolumn{5}{|c|}{ Minimum Density Estimate, Distance among Nests, Territory and Movement for Spizaetus in the Neotropics } \\
\hline Bibliography & Estimates & S. tyrannus & S.melanoleucus & S. ornatus \\
\hline \multirow{4}{*}{$\begin{array}{c}\text { Study case } 1 \\
\text { (Canuto 2009) }\end{array}$} & Dist. among Terriotries & $\mathrm{x}$ & $6.9 \pm 1.5 \mathrm{Km}$ & $6.9 \pm 1.5 \mathrm{Km}$ \\
\hline & Minimum Movement & $\mathrm{x}$ & $4,7 \mathrm{~km}$ & $6.7 \mathrm{~km}$ \\
\hline & Density Estimate in PERD & 1 pair/5373 ha & 1 pair/4285 ha & 1 pair/5373 ha \\
\hline & Distance between nests & $x$ & $13 \mathrm{~km}$ & $x$ \\
\hline \multirow{3}{*}{ Study case 2} & Minimum Defended Territory & 729 ha & $x$ & $x$ \\
\hline & Minimum movement & $1.6 \mathrm{~km}$ & $x$ & $x$ \\
\hline & Dist. among Terriotries & $23 \mathrm{~km}$ & $x$ & $x$ \\
\hline \multirow{3}{*}{ Study case 3} & Forest site occupied & $\mathrm{x}$ & 840 ha & $\mathrm{x}$ \\
\hline & Dist. among Nests & $x$ & $13 \mathrm{~km}$ & $x$ \\
\hline & Minimum Movement & $x$ & $4 \mathrm{~km}$ & $x$ \\
\hline \multirow{4}{*}{ Study case 4} & Forest site occupied & $x$ & $x$ & 1000 ha \\
\hline & Dist. among Terriotries & $x$ & $x$ & $21 \mathrm{~km}$ \\
\hline & Movement & $x$ & $x$ & $4.5 \mathrm{~km}$ \\
\hline & Density Estimate & $x$ & $x$ & 2 pair/70000 ha \\
\hline \multirow{2}{*}{ Study case 5} & Minimum Movement & $10 \mathrm{~km}$ & $x$ & $x$ \\
\hline & Density Estimate & 3 individuals / $10000 \mathrm{ha}$ & $\mathrm{x}$ & $\mathrm{x}$ \\
\hline \multirow{3}{*}{ Thiollay (1989 a) } & Territory & $x$ & 925 to 1090 ha & 1375 ha \\
\hline & Density Estimate & $x$ & 2 pair/4200 ha & 4 pair/10000 ha \\
\hline & Maximum territory size & $x$ & 4200 to $5800 \mathrm{~m}$ & 3000 to $6900 \mathrm{~m}$ \\
\hline \multirow{4}{*}{ Flatten (1990) } & Dist. between nests & $x$ & $x$ & $3.5 \mathrm{~km}$ \\
\hline & Territory & $x$ & $x$ & 977 to 1315 ha \\
\hline & Max. movement from nest & $x$ & $\mathrm{x}$ & $5 \mathrm{~km}$ \\
\hline & Nest density & $\mathrm{x}$ & $\mathrm{x}$ & $1 / 787$ ha \\
\hline \multirow{2}{*}{ Montenegro (1992) } & Male territory & 1090 ha & $x$ & $x$ \\
\hline & Female territory & 1450 to 2470 ha & $\mathrm{x}$ & $\mathrm{x}$ \\
\hline Sixto (1992) & Max. Movements from nest by female & $3 \mathrm{~km}$ & $x$ & $x$ \\
\hline \multirow{3}{*}{ Julio (1991) } & Female territory & $x$ & $x$ & 256 to 2100 ha \\
\hline & Max. Movements from nest by female & $\mathrm{x}$ & $x$ & $5 \mathrm{~km}$ \\
\hline & Max. Movements from nest by male & $x$ & $x$ & $3.3 \mathrm{~km}$ \\
\hline Joenck (2006) & Density estimate & 2 indiv./4500 ha & $x$ & $x$ \\
\hline \multirow{2}{*}{ Canuto (2008) } & Density Estimate & 1 pair/2960 ha & $x$ & 1 pair/4440 ha \\
\hline & Dist. among Terriotries & $5.7 \mathrm{~km}$ & $x$ & $7.9 \mathrm{~km}$ \\
\hline
\end{tabular}

Table 1. Case studies and literature on estimates and patterns of nesting and individuals densities, specimen movements, telemetry gear data and territoriality among Spizaetus.

In the study areas, the use of large trees for nesting by the species $S$. melanoleucus $(\mathrm{N}=4)$ and S. ornatus $(\mathrm{N}=3)$ is evident. The location of the reproduction sites for the three species of the genus also coincided with areas of rugged terrain, valleys and forested ravines, which are favorable for isolation or areas with difficult access for human activities, according to Silva et al. (2007) (Figure 1, Photo 2 and 3).

In areas with patches of 6,000 to $12,000-36,000$ ha, in contiguous or protected remnants, it is possible to perceive the incidence of the three different species in the same fragment. It is 
also possible to observe population patterns, regarding the defense of different neighboring areas, through mapping and reproductive behavior. These may be considered to be refuges for reproductively active populations, although they are isolated at a regional level. Only large fragments with mature forests are capable of preserving sensitive species, especially those with large area requirements (Ferraz et al. 2007) or with strict habitat requirements, whose survival is particularly problematic in the present fragmented state (Aleixo 1999; Ribeiro et al. 2009). Therefore, these species, though present in extensive or contiguous forest environments, have low density and are naturally rare in the landscape, according to characteristics that are sparse in the environment, (for example Nesting areas; photo 4, Newton 1979). Thus, these ecological parameters make them even more susceptible to fragmentation (Laurance et al. 1997, Henle et al. 2004).

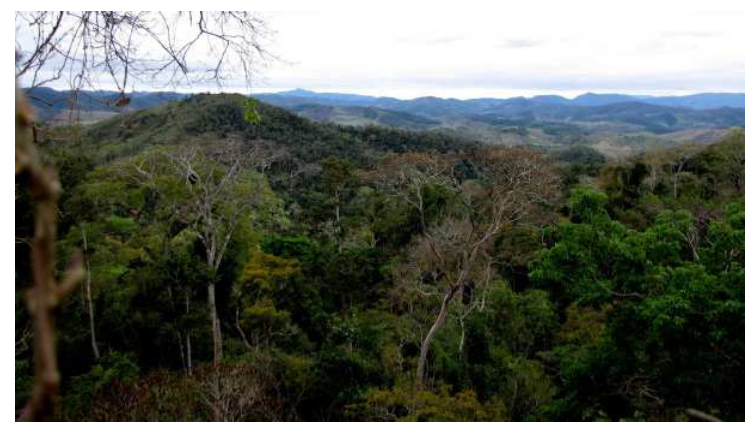

Photo 4. Black-and-white hawk-eagle nesting site. Photo credit: Marcus Canuto

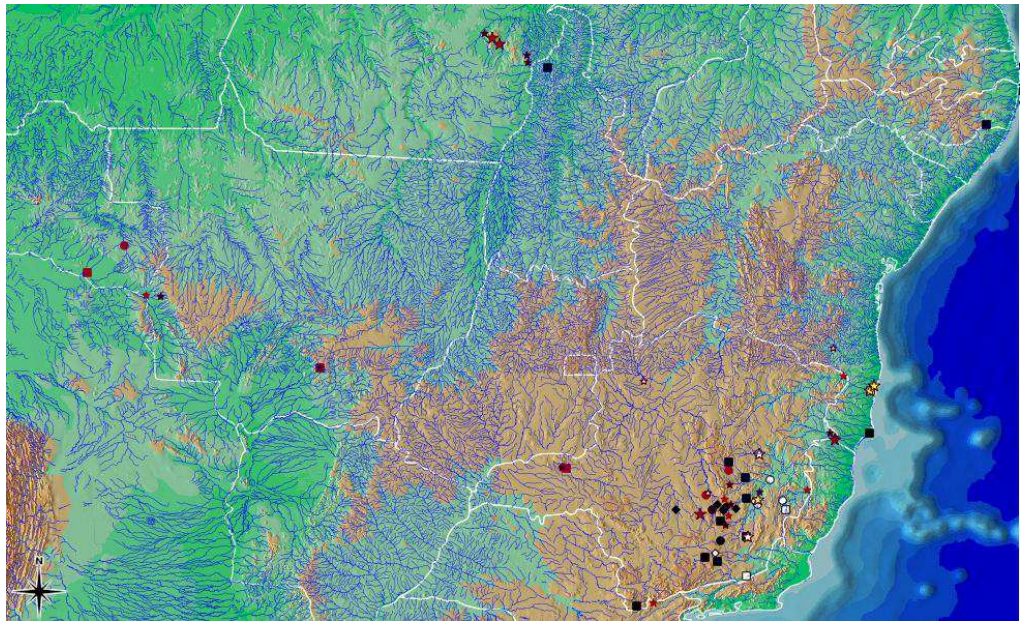

Fig. 1. Map of Spizaetus records in the Atlantic Rainforest and Amazon; squares indicate records of pairs, circles indicate nests and diamonds indicate records from cited literature. Big stars indicate the incidence of the three species of Spizaetus (yellow), or of two, S. ornatus and S. tyrannus (brown with black), and S. tyrannus and S. malanoleucus (white with black). Small stars indicate records of species in this study. In general, white is for S. malanoleucus, black is for S. tyrannus and brown is for S. ornatus. Scale: 1:10685101. 
The distance of $25 \mathrm{~km}$ from most remaining fragments of Atlantic Rainforest to its largest reserves (Ribeiro et al. 2009) presents serious conservation problems even for medium sized birds according to the patterns and estimates of movement and density presented (Table 1).

According to the biometrics of the nesting trees previously discussed, we observe a tendency of the species S. melanoleucus in using emergent or mature trees in inland Atlantic Forest and transition areas, as does S. ornatus. For S. tyrannus, according to Sixto (1992) and the nest monitored, the species used medium sized trees $(20-25 \mathrm{~m})$ for nesting. According to case study 3, in the highly fragmented region of Governador Valadares, an active Spizaetus melanoleucus' nest was located in an area mostly covered by Eucalyptus sp. The nest was located in a fragment of approximately 1,293 hectares, with an area roughly evaluated to be $70 \%$ covered by Eucalyptus. However, the presence of an emerging tree for nesting, isolated from the rest of the vegetation, in a drainage system of difficult access, near extensive bodies of water and riparian vegetation, are probably decisive factors in the occupation of this territory. The population maintenance of these species depends on creating or increasing wildlife corridors, due to the large life area required by the taxon. A better evaluation is needed on the dispersion pattern of adults and youngsters throughout the various fragments in a mosaic of altered environments, as well as the selection of nesting areas (see Table 2).

\begin{tabular}{|c|c|c|c|c|c|c|}
\hline \multicolumn{7}{|c|}{ Characterization on areas of nests and records on pairs } \\
\hline Study case & Species & Record & Site & $\begin{array}{c}\begin{array}{c}\text { Forest site of the } \\
\text { record }\end{array}\end{array}$ & Landscape Features & Habitat \\
\hline 1 and 3 & S. melanoleucus & Nest & Baixa Verde MG & 1700 ha & Forested slope, valley and lakes & Tall protected forest \\
\hline 1 and 3 & S. melanoleucus & Nest & PE Rio Doce MG & $36000 \mathrm{ha}$ & Lowland forest, small valleys and lakes & Tall protected forest \\
\hline 2 & S. tyrannus & Pair & Ibertioga MG & $x$ & Slope, valleys and forested hill tops & Late seconday growth \\
\hline 2 & S. tyrannus & Pair & Ibertioga MG & $x$ & Slope and forested hill tops & Late seconday growth \\
\hline 2 & S. tyrannus & Nest & Caranaiba MG & 179 ha & Valeys and forested hill tops & Early secondary growth \\
\hline 3 & S. melanoleucus & Nest & Governador Valadares MG & 1293 ha & Lowl and forest, Eucalyptus plantations and valleys & Early secondary growth \\
\hline 3 & S. melanoleucus & Nest & São Pedro do Suaçuí MG & $x$ & Valeys and forested hill tops & Early secondary growth \\
\hline 3 & S. melanoleucus & Nest & RPPN Miguel Abdala, Caratinga MG & $1000 \mathrm{ha}$ & Valeys and forested hill tops & Tall protected forest \\
\hline 5 & S. ornatus & Nest & Uberlândia MG & 1000 ha & Forested valley & Early secondary growth \\
\hline 5 & S. ornatus & Pair & Uberlândia MG & $1000 \mathrm{ha}$ & Forested valley & Early secondary growth \\
\hline 6 & all 3 Spizaetus & Incidence & PN do Pau Brasil, Porto Seguro BA & $12000 \mathrm{ha}$ & Lowland forest with valley formations & Tall protected forest \\
\hline 6 & all 3 Spizaetus & Incidence & Estação Veracel & $6000 \mathrm{ha}$ & Lowland forest with valley formations & Tall protected forest \\
\hline 6 & S. melanoleucus & Pair & PN do Pau Brasil, Porto Seguro BA & $12000 \mathrm{ha}$ & Lowland forest with valley formations & Tall protected forest \\
\hline Pers. comm. 1 & S. tyrannus & Pair & Antônio Dias & $x$ & Slope, valleys and forested hill tops & Late seconday growth \\
\hline Pers. comm. 2 & S. tyrannus & Pair & São Bartolomeu/Ouro Preto MG & 2846 ha & Slope, valleys and forested hill tops & Early secondary growth \\
\hline Pers. comm. 3 & S. tyrannus & Pair & Serro MG & $x$ & Cerrado of altitude, deciduous and semideciduous forest & Early secondary growth \\
\hline $\mathrm{x}$ & S. melanoleucus & Pair & Além Paraiba MG & 840 ha & Valeys and forested hill tops & Late seconday growth \\
\hline $\mathrm{x}$ & S. tyrannus & Pair & Camanducaia MG & $410 \mathrm{ha}$ & Montane forest and slope & Late seconday growth \\
\hline $\mathrm{x}$ & S. tyrannus & Young and adults & Nova Lima, MG & $343 \mathrm{ha}$ & Monatne forest, valleys and forested hill tops & Late seconday growth \\
\hline $\mathrm{x}$ & S. melanoleucus & Pair & São José do Mantimento MG & 966 ha & Lowland forest and valleys & Early secondary growth \\
\hline $\mathrm{x}$ & S. ornatus & Nest & Matozinhos MG & $900 \mathrm{ha}$ & Cerrado, deciduous and semideciduous forest & Early secondary growth \\
\hline
\end{tabular}

Table 2. Characteristics of some of the areas, and records used in the case studies to illustrate area sizes in hectares whereas records of the three species took place. Personal communication 1 (Gustavo Pedersoli); personal communication 2 (Frederico Pereira de Castro Andrade); personal communication 3 (Estefane N. L. Siqueira).

For S. ornatus and S. tyrannus, case studies 2 and 4, the density estimation is lower in fragmented areas. There are two pairs with approximately $20 \mathrm{~km}$ between them. In extensive fragments, there are two pairs every $5.3-13 \mathrm{~km}$, according to mapping and estimations for the three species (case study 1; Canuto 2008a). According to Ribeiro et al. (2009) the average isolation between forest fragments along the Atlantic Rainforest extension is $1.4 \mathrm{~km}$, varying from a few meters to dozens of kilometers. By removing fragments smaller than 50 hectares from the equation, the isolation between fragments 
increases to $3.5 \mathrm{~km}$, and by removing fragments up to 200 hectares, this average isolation becomes $8 \mathrm{~km}$.

Therefore, the existing and continuous fragmentation of the biome has isolated populations and individuals, and is still continuously depleting prey resources and top predator populations (according to Newton 1979, Thiollay 1989a, 2007). Jullien and Thiollay (1996), in the French Guiana, after extensive sampling with various habitats and gradients of anthropogenic degradation, described the decline and loss of forest species and their substitution by more generalist and open habitat species.

According to Harestad and Bunnell (1979), Schoenerand and Schoener (1982), and Kennedy et al (1994) cited in Perry (2000), the interspecific variations in the life size areas, which were not evaluated in this study, have also been correlated to age, sex and seasons. Therefore, according to Table 1, the differences between values derived from the different methods, environments, ecological patterns and specimens. However, we emphasize that, regardless of the differences, there is evidence of great dislocations in kilometers in fragmented and continuous environments, low density of the species in the area and reproduction sites in all the studies. There is also incidence of the species in environments or sites that have characteristics such as isolation, difficult access (rugged topography), and the presence of bodies of water and mature trees for nesting. Also, certain local populations are present along extensive protected forest areas, that are however isolated from the Atlantic Rainforest.

For Salvador-Jr. et al (2011), 16 records of the species $S$. tyrannus were obtained in an area of 720,000 hectares, including 37 municipalities, known as the "Quadrilátero Ferrífero" (Iron Quadrilateral) in the mountain formations in the state of Minas Gerais. According to these authors, the region has been under great pressure from mining and deforestation throughout its colonization history. In the previous and present studies, 23 sites were contemplated for the species, with the farthest points covering a range of approximately 200sq. $\mathrm{km}$ in fragmented environments. The records show an average distance of $18.8+\ldots 11$, varying between $40 \mathrm{~km}$ and $8 \mathrm{~km}$. Thus, we point out that the "Quadrilátero Ferrífero" is of extreme importance for conservation of potential reproductive populations of the species.

In Mendonça-Lima et al. (2006) several records were made of S. ornatus and its respective geographical locations in the south of the country generally associated with preserved forest portions. However, the authors suggest more efforts are needed to conserve this species in the south of the country, with the species having been sub-sampled, which is partly due to their refuge in environments of difficult access. Still regarding the southern Atlantic Rainforest, Joenck (2006) recorded the species Spizaetus tyrannus in several occasions in a preservation park, estimating two individuals in 4,500 hectares (Table 1).

In the northeast, the Endemism Center of Pernambuco, the species S. tyrannus was recorded as shown in Figure 1. According to Carlos and Girão (2006), still in the northeastern Atlantic Rainforest, the species S. ornatus may never have occurred, such as $S$. melanoleucus that were never recorded in the region. However, we emphasize the sub-sampling problems, inadequate methods, prior to habitat fragmentation, which may have made this/these species extinct in the state, according to previously cited studies.

In the case of nest records or pairs incidence for the genus in the Brazilian Amazon (Figure 1), these records were associated to extensive forests or mosaics of continuous 
environments, but also to fragmented areas. The presence of extensive source areas may complicate an evaluation on territoriality or density in the Amazon Forest, or fragments of the forest, according to the recruiting of individuals. S. tyrannus was recorded in extremely fragmented areas, with records of pairs in areas distanced between 22 and $67 \mathrm{~km}$, with open and altered environmental mosaics among these, as well as in portions of continuous forest, with records of two specimens exhibiting territorial behavior distanced in $28 \mathrm{~km}$. However, possible gaps or occupied territories among these were not evaluated in the continuous areas. S. ornatus, in the Amazon, was only recorded in continuous or extensive fragments, forests with a minimum of dozens of kilometers in extension.

\section{Conclusion}

Alvarez et al. (1996) obtained throughout five years in Venezuela, during hike and drives, one record of S. melanoelucus, two records of S. ornatus and four records of $S$. tyrannus. These species were seen in areas that suffer from selective logging, monoculture plantations, clearings and other altered environments. The authors attested that methods for censuses of birds of prey must be complemented with observations above the forest canopy. This warranted the evaluation in this study conducted with appropriate techniques for the visualization of these species, presenting results of low frequency occurrence and low density for S. melanoleucus and S. ornatus in the fragmented areas, which shows a greater sensibility to these environmental changes for both species.

Some authors consider Spizaetus tyrannus less sensitive to fragmentation than its congeners because it is observed more frequently in fragmented areas (Table 2) and altered forests (Brown and Amadon, 1968; Jullien and Thiollay, 1996; Thiollay, 2007). In addition, there are recent records of their occurrence in fragments near major urban centers (Azevedo et al. 2003, Zorzin et al. 2006, Canuto 2008, Salvador-Jr et al. 2011).

We obtained sparse or isolated records of its congeners S. melanoleucus and S. ornatus in the different case studies. This loss of sympatry (presence of sister species in the same place), previously cited and evident in extensive or continuous areas (case study 1), shows a lesser sensibility of the species $S$. tyrannus to fragmentation when compared to its congeners in the Atlantic Rainforest, where the species' natural distribution would be throughout all of the biome (Brown and Amadon 1968, del Hoyo et al. 1994, Ferguson-Lees and Christie 2001). According to Canuto (2008a), in the lowland tropical rainforest of Panama, the density of the group was higher than that of case study 1 (semideciduous Atlantic Forest), with the use of quite different methods in each study, random hikes and direct observation of the canopy respectively, but with the same sampling effort (approximately 550 hours). Thus, for the group, both methods are essential and complementary, with the need of continuous efforts and several counts or annual campaigns. Therefore, according to these density differences we can infer, primarily, that Hawk-eagles in less productive areas should be spaced further apart than those in more productive areas (Hustler and Howells, 1988). According to Lyon and Kuhnigk (1985), a region with higher primary productivity should support a higher density of Hawk-eagles. This was attested here for S. tyrannus and S. ornatus, according to Canuto (2008a) study but not for the few unclear results showed here for the Amazon forest, in comparison with study case 1. 
Also it's important to show that populations, in Amazon forest or other tropical or subtropical forets (Canuto 2008a, Carvalho-Filho 2009, Canuto 2009, Thiollay 1989a, 2007), on large or protected areas, includes 2-3 Spizaetus species at the same sites or portions of mature forest. Also according to the cited studies the species are of low densitie even at large portions of mature forest. At Minas Gerais state, those, earlier sympatric species, are being separated or already are, through local extinction, on several regions by deforestation, with exception of one extensive reserve in Minas Gerais as PERD (study case 1), or probably just a few other areas.

Also, as evaluated by Carvalho and Marini (2007), urbanization led to a loss of one-third of diurnal raptors at the surrounding areas of the Minas Gerais state capital, Belo Horizonte, including all three Spizaetus, that became extremely rare or probably extinct.

Azevedo et al (2003) recorded several times two individuals together of $S$. tyrannus at an island of approximately $42300 \mathrm{ha}$, apart from the main land approximately by $2-10 \mathrm{~km}$, at Santa Catarina state, on the Atlantic rainforest domain south of Brazil. No other taxon from Spizaetus was recorded or estimates on density were made.

Therefore, the local decline and extinction of forest raptors in the Atlantic Rainforest, with their posterior substitution by countryside generalist taxons, due to deforestation of tropical forests, is very worrying and documented in several studies (Thiollay 1985, Albuquerque 1986, Ellis et al. 1990, Jullien and Thiollay 1996, Sick 1997, Seavy and Apodaca 2002, Salvador-Jr. and Silva 2009, Zorzin 2011).

Along with the loss of habitats, the local preservation of the genus Spizaetus may be affected by selective logging, since these species use large trees to build their nests (Brown and Amadon 1968, Lyon and Kuhnigk 1985, Montenegro et al. 1992, Canuto 2008), and these evidences of suppression of emergent trees was evidentiated on several occasions at the Minas Gerais state (personal communication by the authors), furthermore, these trees and nesting sites are sparse or rare in already fragmented habitats.

Due to the extinction of those species on several locations of the Atlantic rainforest its fundamental the creation of a bridge between technical-scientific knowledge and public opinion through environmental education and publicizing results and conservation programs, as well as the creation of wildlife corridors. The examples of pressure of deforestation of areas surrounding conservation parks and along the Atlantic Rainforest due to mining, selective logging and fragmentation, as well as changes in the Brazilian Forest Code, and hunting and poaching of the group's species, are all directly linked to the public opinion in rural communities and environmental sectors of the municipal, state and federal governments. This consequently influences the preservation of the Atlantic Rainforest habitat, along with the Spizaetus group and other indicator or rare species.

According to Figure 2, the central east, northeast, south and west of the state of Minas Gerais and the south of the state of Bahia are extremely important for the preservation and study of the genus. Including areas of natural incidence or occurrence, these portions include the middle basin of the Doce river, the south-central section of the Espinhaço mountain chain, the Mantiqueira mountain chain, MG transition cerrado areas in the Triângulo Mineiro Region and the northeast and northwest (insufficient data) part of the state, and the boundarie between the states of Minas Gerais and Bahia. 


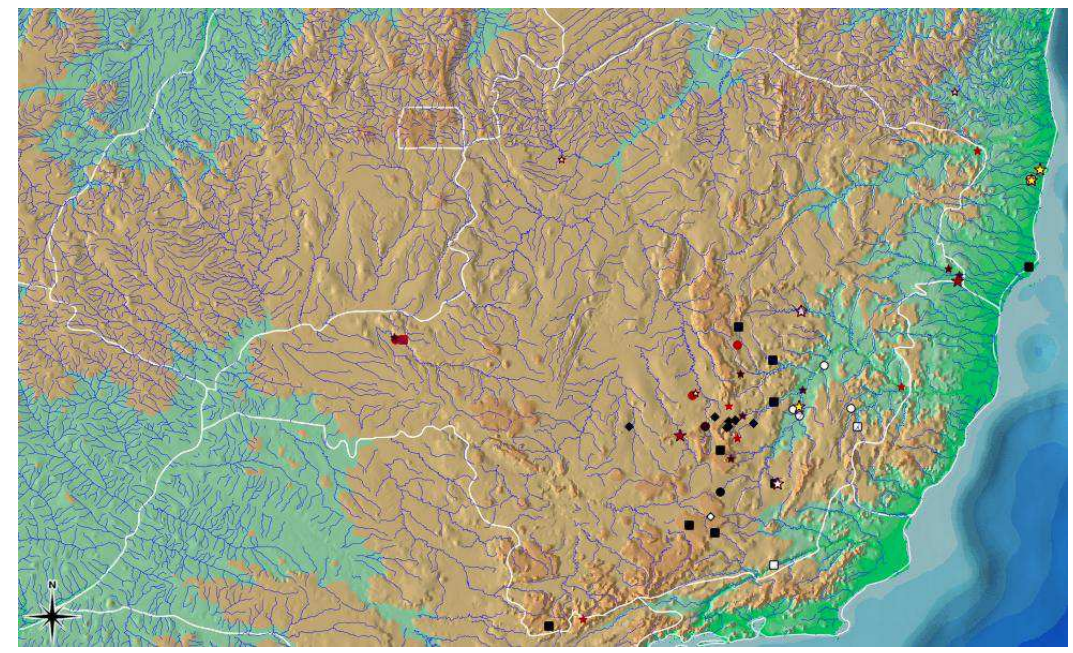

Fig. 2. Map of Spizaetus records in the Atlantic Rainforest; squares indicate records of pairs, circles indicate nests and diamonds indicate records from cited literature. Big stars indicate the incidence of the three species of Spizaetus (yellow), or of two, S. ornatus and S. tyrannus (brown with black), and S. tyrannus and S. melanoleucus (white with black). Small stars indicate records of species in this study. In general, white is for S. melanoleucus, black is for S. tyrannus and brown is for S. ornatus. Scale: 1:5036552.

Several unpublished records of most of individuals, from different observers, were not used on the assessments. This work focus in population status at some regions, pairs, young and nests, than distribution or occurrence. Therefore according to the pattern of specimen movements, several kilometers, and due to human persecution or deforestation pressure, these could lead certain species to wander throughout the regions, mistaken the actual active breeding population with isolated records of individuals in dispersal or other.

We also have to realize that the few or absent records on fledged youngs, meaning reproductive success, at least in Minas Gerais state, are a crucial alert to lack of active breeding populations, yet to be evaluated for future conservation plans for the medium or large birds of prey. As any charismatic or umbrela species, that figures as conservation flags for any threatened environments, predators generally uses extensive portions of mature, or protected, or in need to protection, forest habitats, and therefore could provide and serve as conservation flags for our natural resources and those of local communities.

\section{Acknowledgments}

We would like to thank Biocev Serviços de Meio Ambiente and staff, the Veracel Station and staff, the administration of PARNA do Pau Brasil and staff, Tânia Sanaiotti (INPA), the Instituto Estadual de Florestas (State Forest Institute), the staff and all the surrounding communities of the "Parque Estadual do Rio Doce", The Peregrine Fund, the Federal University of Ouro Preto staff, teachers, students, city community and CAPES, and the Federal University of Viçosa. Also the collaborators Fernanda Pedreira Tabacow, Breno G. M. da Silva, Carla de Borba Possamai and staff of the RPPN Miguel Feliciano Abdala-FMA, 
Charles Lopes Moreira and Djalma de Carvalho Junior, Geraldo dos Santos Adriano (Canela) Fabiano R. Melo, Marcelo Ferreira Vasconcelos, Frederico Pereira de Castro Andrade, Gustavo Pedersoli, Luiz Gabriel Mazzoni, Alyne Perillo, and Estefane N. L. Siqueira for their valuable contribution in recording data.

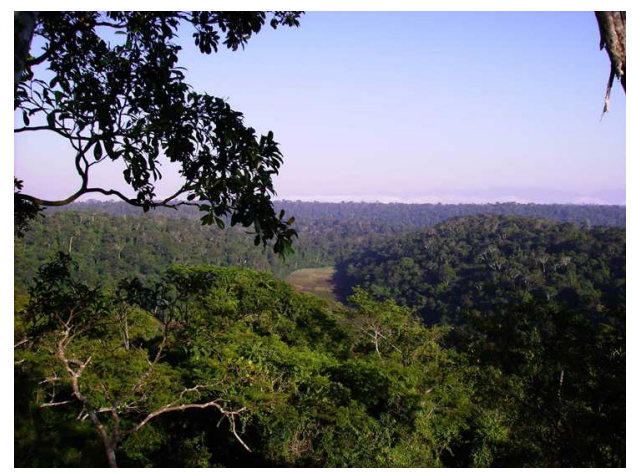

Photo 5. Point count in the canopy (Study case 1). Photo credit: Marcus Canuto

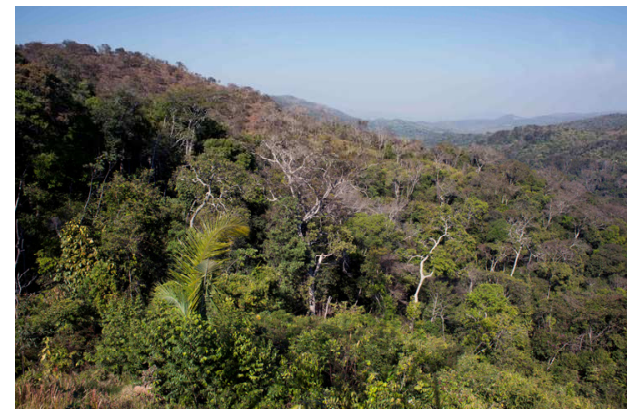

Photo 6. Galery forest, Cerrado-Amazon forest, Mato Grosso state, site of incidence of $S$. ornatus. Photo credit: Eduardo Pio Carvalho

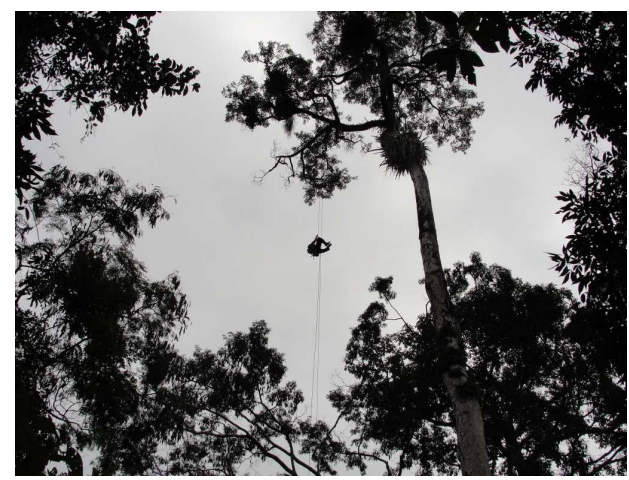

Photo 7. Climbing techiniques to access Black-and-white Hawk-eagle nest for measurements. Study case 3. Photo credit: Breno G M da Silva 


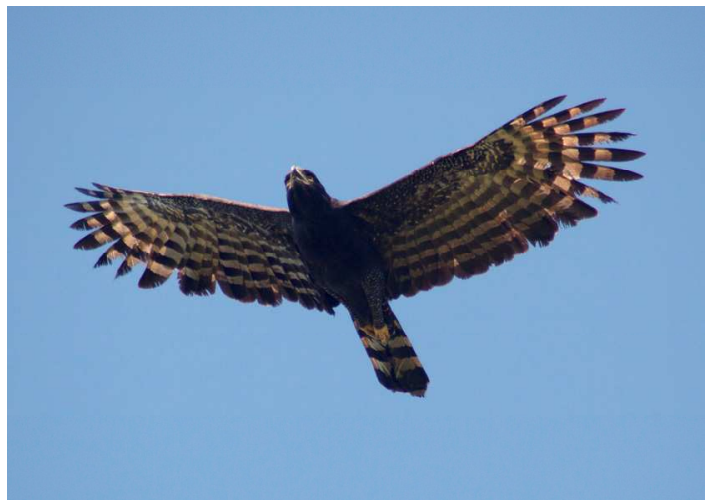

Photo 8. Adult individual of S. tyrannus on flight. Photo credit: Eduardo Pio Carvalho

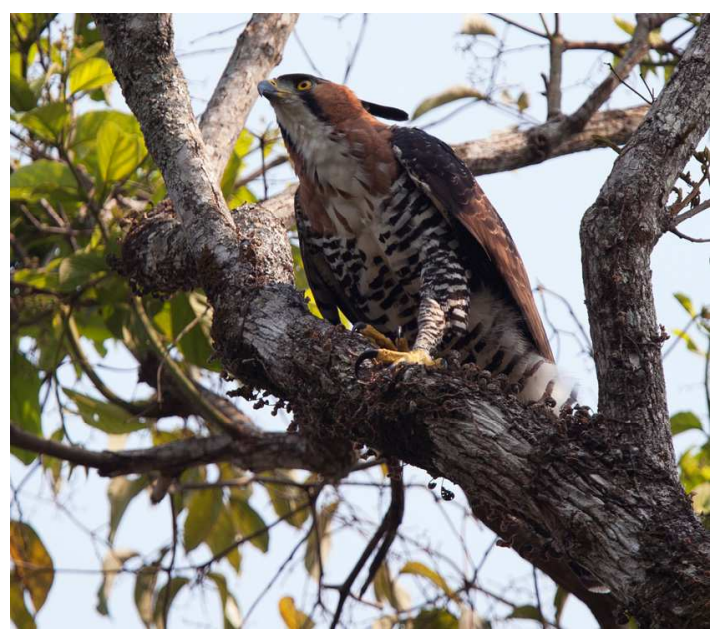

Photo 9. Adult individual os S. ornatus. Photo credit: Eduardo Pio de Carvalho

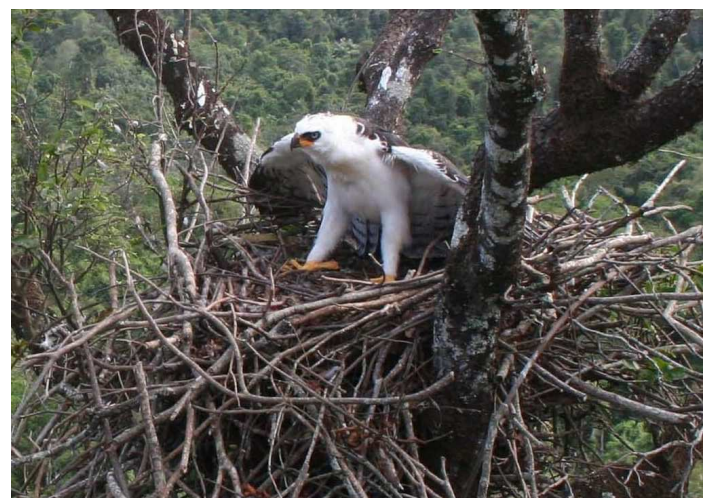

Photo 10. Fledgling of S. melanoelucus in the nest. Photo credit: Carlos Eduardo Carvalho 


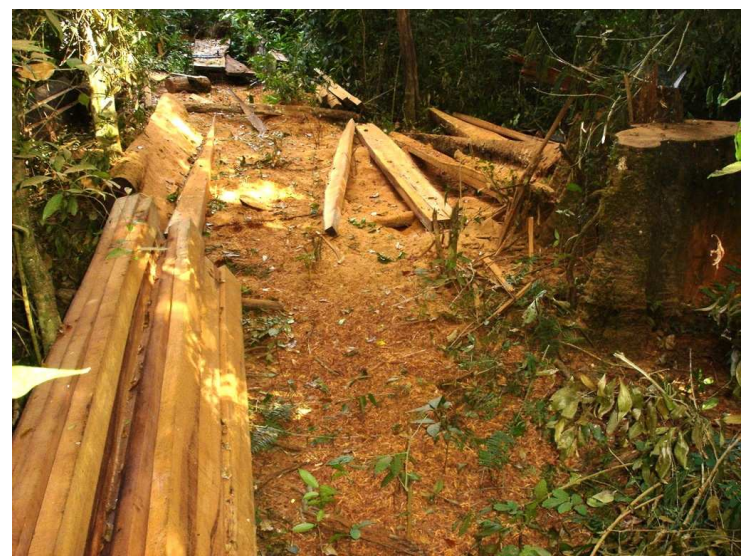

Photo 11. Selective logging, Viçosa, Minas Gerais. Photo credit: Giancarlo Zorzin

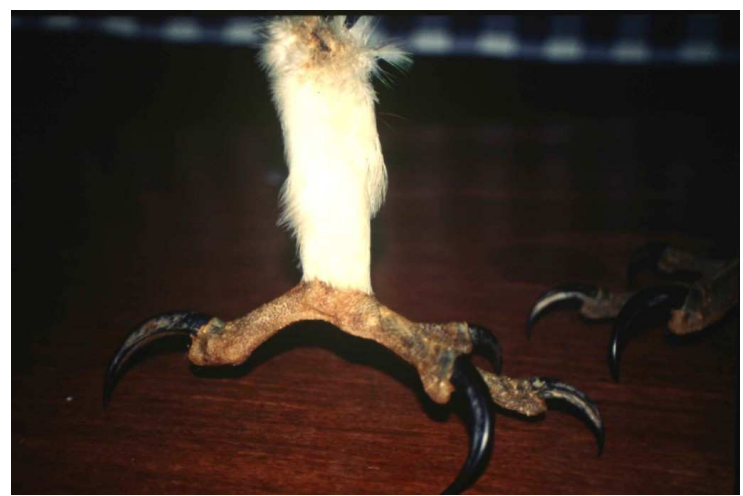

Photo 12. Tallon of hunted Spizaetus specime. Photo credit: Gustav Specht

\section{Filliation universities and institutions}

Some of the data were presented as part of master degree programs at Universidade Federal de Ouro Preto - PPG Ecologia de Biomas Tropicais, and Universidade Federal de Viçosa Museu de Zoologia João Moojen. Those dissertations were supported by the scientific scholarship CAPES and The Pregrine Fund, Boise state, Idaho, USA.

\section{References}

Albuquerque, J.L.B. 1995. Observations of rare raptors in southern Atlantic rainforest of Brazil.Journalof Field Ornithology 66: 363-369.

Alvarez, E., D. H. Ellis, D. G. Smith, and C. T. Larue. 1996. Diurnal raptors in the fragmented rain forest of the Sierra Imataca, Venezuela. Pages 263-273 
ANA, 2001.Proposta de Instituição do Comitê de Bacia Hidrográfica do Rio Doce, donforme Resolução No 5, de 10 de Abril de 2000, do Conselho Nacional De Recursos Hídricos.

Azevedo, M.A.G., Machado, D.A. e Albuquerque, J.L.B. 2003. Aves de rapina na Ilha de Santa Catarina, SC: composição, freqüência de ocorrência, uso do habitat e conservação. Ararajuba, 11 (1):75-81.

Bergallo, H. G., C. F. D. Rocha, M. A. S. Alves and M. Vansluys.2000. A fauna ameaçada de extinção do Estado do Rio de Janeiro. . 1vols, p. 166. Rio de Janeiro: EdUERJ.

Bibby, C.J., Burgess, N.D., Hill, D.A., Mustoe, S.H., 2000.Bird Census Techniques, 2nd ed. Academic Press, London.

Bierregaard, R.O., Jr. 1998. Conservation status of birds of prey in the South American tropics. Journal of Raptor Research 32: 19-27

Bildstein, K. L. 1998. Linking raptor migration science to mainstream ecology and conservation: an ambitious agenda for the 21 stcentury.Pages 583-602 in Holarctic birds of prey (B.-U.Meyburg, R. D. Chancellor, and J. J. Ferrero, Eds.).ADENEX, Merida, Spain; and World Working Group for Birds of Prey and Owls, Berlin, Germany.

Blake, E.R.1977. Manual of neotropical birds. The University of Chicago Press, Chicago and London.

Brown, L. and D. Amadon. 1968. Eagles, hawks, and falcons of the world. v.1 and 2. Country Life Books, London.

Burnham, W. A., D. F. Whitacre, and J. P. Jenny, (eds). 1990. Progress report III, 1990: Maya Project--use of raptors as environmental indices for design and management of protected areas and for building local capacity for conservation in Latin America. The Peregrine Fund, Inc., Boise, Idaho.201 pp.

Burnham, W. A., D. F. Whitacre, and J. P. Jenny. 1994. The Maya Project: use of raptors as tools for conservation and ecological monitoring of biological diversity. pp. 257-264 in B.-U.Meyburg and R. D. Chancellor, eds., Raptor conservation today.World Working Group on Birds of Prey, The Pica Press.

Canuto, M. 2008a. Observations of two hawk eagle species in a humid lowland tropical forest reserve in Central Panama. Journal of Raptor Research 42 (4): 287-292.

Canuto, M. 2008b. First description of the nest of the black-and-white hawk eagle (Spizaetusmelanoleucus) in the Brazilian Atlantic Rainforest, southeast Brazil.Neotropical Ornithology 19: 607-610.

Canuto, M. (2009). Ecologia de comunidades de aves de rapina (Cathartidae, Accipitridae e Falconidae) em fragmento de Mata Atlântica na região do médio Rio Doce, MG. Dissertação de Mestrado. Ouro Preto: Universidade Federal de Ouro Preto.

Carlos, C.J. and W. Girão. 2006. [The history of the Ornate Hawk-Eagle, Spizaetusornatus, in the Atlantic forest of northeast Brazil]. Revista Brasileira de Ornitologia 14:405-409.

Carrascal, L.M.; Palomino, D. Polo, V. 2008a. Patrones de distribución, abundancia y riqueza de especies de la avifauna terrestre de la isla de La Palma (islas Canarias). Graellsia 64: 209-232. 
Carrascal, L.M.; Seoane, J.; Palomino, D.; Polo, V. 2008b. Explanations for bird species range size: ecological correlates and phylogenetic effects in the Canary Islands. JournalofBiogeography35:2061-2073.

Carvalho, C. E. A. \& M. Â. Marini. 2007. Distributional patterns of raptors in open and forested habitats in Southeast Brazil and effects of urbanisation. Bird Conservation International 17: 367-380.

Carvalho-Filho, E. P. M., Carvalho, C. E. A. e Carvalho, G. D. M. 1998. Descrição de ninho e ovos de Micrastur semitorquatus (Falconidae) no interior de habitação rural, no município de sete lagoas - MG. Atualidades Ornitológicas, 86: 12.

Carvalho Filho, E. P. M., Carvalho, G. D. M. e Carvalho, C.E.A. 2005. Observations of nesting Gray-Headed Kites (Leptodon cayanensis) in southeasters Brazil. Journal Raptor Research, 39 (1): 91-94.

Carvalho Filho, E.P.M., Canuto, M. e Zorzin, G. 2006. Biologia reprodutiva do gavião preto (Buteogallus u. urubitinga: Accipitridae) no sudeste do Brasil. Revista Brasileira de Ornitologia, 14 (4): 445-448

Carvalho Filho, E.P.M., Zorzin, G., Canuto, M., Carvalho, C.E.A. \& Carvalho, G.D.M. 2008. Aves de rapina diurnas do Parque Estadual do Rio Doce, Minas Gerais, Brasil. Instituto Estadual de Florestas - MG.Biota v.1.n.5. ISSN 1983-3678.

Carvalho Filho, E. P. M., Zorzin, G., Canuto, M., Carvalho, C. E. A. e Carvalho, G. D. M. 2009. Aves de Rapina Diurnas do Parque Estadual do Rio Doce. MG Biota, 1(5): 0443.

CETEC. 1981. Vegetação do Parque Florestal do Rio Doce. Programa de Pesquisas Ecológicas no Parque Florestal Estadual do Rio Doce. Relatório Final, Vol. 2. Fundação Centro Tecnológico de Minas Gerais (CETEC), Belo Horizonte. 277pp.

del Hoyo, Josep, Andrew Elliott, JordiSargatal, et al. 1994. Handbook of the birds of the world: Vol. 2. New World Vultures to GuineafowlLynx Edicions. Barcelona. 638 pg.

Dias, D F ; Rodrigues, M. . Registro do gavião-pombo-pequeno Leucopternis lacernulatus em Belo Horizonte, Minas Gerais. Atualidades Ornitológicas, v. 147, p. 20-21, 2009.

Drummond, G. M.; Machado, A. B. M.; Martins, C. S.; Mendonça, M. P.; Stehmann, J. R. Listas vermelhas das espécies de fauna e flora ameaçadas de extinção em Minas Gerais. 2 ed. Belo Horizonte, MG: Fundação Biodiversitas, 2008.

Faria, L.C.P., L.A. Carrara, F.Q. Amaral, M.F. Vasconcelos, M.G. Diniz, C.D. Encarnação, D. Hoffmann, H.B. Gomes, L.E. Lopes and M. Rodrigues. 2009. The birds of Fazenda Brejão: a conservation priority area of cerrado in northwestern Minas Gerais, Brazil. Biota Neotropica 9(3): 223-240.

Ferguson-Lees, J. \& Christie, D.A. (2001) Raptors of the world. Christopher Helm, London.

Ferreira, R. L. and M. M. G. S. M. Marques. 1998. A Fauna de Artrópodes de Serapilheira de Áreas de Monocultura com Eucalyptussp e Mata Secundária Heterogênea. Anais da Sociedade Entomológica do Brasil 27:395-403.

Flatten, C.J. 1990. Biology of the Ornate Hawk-Eagle (Spizaetusornatus). Pages 129- 143 in W.A. Burnham, D.F. Whitacre, and J.P. Jenny [EDS.], Maya Project: use of raptors as environmental indices for design and management of protected areas for 
building local capacity for conservation in Latin America, progress report III. The Peregrine Fund Inc., Boise, ID U.S.A.

Fontana, C. S., Bencke, G. A. e Reis, R. E. (orgs.). 2003. Livro vermelho da fauna ameaçada de extinção no Rio Grande do Sul. Porto Alegre: EDIPUCRS.

Francischetti CN. 2007. Ephemeroptera (Insecta) do Parque Estadual do Rio Doce, Minas Gerais, Brasil: Biodiversidade e distribuição espacial. D.S. Thesis, Universidade Federal de Viçosa. 97 pp.

Helbig, A.J., A. Kocum, I. Seibold, and M.J. Braun. 2005. A multi-gene phylogeny of aquiline eagles (Aves: Accipitriformes) reveals extensiveparaphyly at the genus level. Molecular Phylogenetics and Evolution 35:147-164.

Gilhuis, J.P. 1986. Vegetationsurveyofthe Parque Florestal Estadual do Rio Doce, MG, Brazil. Tese de Mestrado, Agricultural University of Wageningen, Netherlands.Viçosa, Universidade Federal de Viçosa/AgriculturalUniversityof Wageningen. $86 \mathrm{pp}$

Gjershaug, J. O., N. Røv, T. Nygård, D. M Prawiradilaga, M. Y. Afianto and Hapsoro, and A. Supriatna. 2004. Home-range size of the Javanhawk-eagle (Spizaetusbartelsi) estimated from direct observations and radiotelemetry. Journal of Raptor Research 38:343-349.

Granzinolli, Marco AntonioMonteiro ; Motta-junior, J. C. . Aves de rapina: levantamento, seleção de habitat e dieta. In: Von Matter, S.; Straube, F.; Accordi, I.; Piacentini, V.; Cândido Jr., F. J.. (Org.). Ornitologia e conservação: ciência aplicada, técnicas de pesquisa e levantamento. 1 ed. Rio de Janeiro: Technical Books editora, 2010, v., p. 169-187

Griffiths, C.S., G.F. Barrowclough, J.G. Groth and L.A. Mertz. 2007. Abstract: Phylogeny, diversity, and classification of the Accipitridae based on DNA sequences of the RAG-1 exon. pp.22 In Program and abstracts: Kettling on the Kittatinny 12-16 September 2007, Holiday Inn Conference Center, Lehigh Valley, Fogelsville, Pennsylvania. Raptor Research Foundation and Hawk Migration Association of North America, Fogelsville, PA.

Haring, E. et al., 2007.Convergent evolution and paraphyly of the hawk-eagles of the genus Spizaetus [Aves, Accipitridae] - phylogenetic analyses based on mitochondrial markers. Journal of Zoological Systematics and Evolutionary Research 45: 353-365).

Hirsch, A. 2003a. Avaliação da Fragmentação do Habitat e Seleção de Áreas Prioritárias para a Conservação dos Primatas da Bacia do Rio Doce, Minas Gerais, Através da Aplicação de um Sistema de Informações Geográficas. Tese de Doutorado. Programa de Pós-Graduação em Ecologia, Conservação e Manejo de Vida Silvestre, ICB / UFMG, Belo Horizonte. 227pp + Anexos.

Hirsch, A. 2003b.Habitat fragmentation and priority areas for primate conservation in the Rio Doce Basin, Minas Gerais.Neotropical Primates, 11(3):195-196.

Hustler, K. and Howells, W.W. 1988. The effect of primary production on breeding success and habitat selection in the African Hawk-Eagle. Condor 90:583--587

IBGE. 2003. Base Cartográfica Integrada do Brasil ao Milionésimo Digital - bCIMd. Versão 1.0. Fundação Instituto Brasileiro de Geografia e Estatística, Rio de Janeiro. 8pp. 
Joenck, C.M. 2006. [Records oftheSpizaetustyrannus (Acciptridae) in the Centro de Pesquisa e Conservação da NaturezaPró-Mata (CPCN Pró-Mata) in northeast of the state of Rio Grande do Sul, Brazil] .RevistaBrasileira de Ornitologia 14:427-428

Jullien, M. and J.M. Thiollay. 1996. Effects of rain forest disturbance and fragmentation: comparative changes of the raptor community along natural and human-made gradients in French Guiana. Journal of Biogeography 23(1): 7-25.

Julio, A., Madrid, M., Héctor, D., Sixto H., Funes, A., Lopez, J., Botzoc, G.R. and Ramos, A. 1991. Reproductive biology and behavior of the Ornate Hawk-Eagle (Spizaetus ornatus) in Tikal National Park. Pages 93-13 in W.A. Burnham, D.F. Whitacre, and J.P. Jenny [EDS.], Maya Project: use of raptors and other fauna as environmental indices for design and management of protected areas for building local capacity for conservation in Latin America, progress report IV. The Peregrine Fund Inc., Boise, ID U.S.A.

Kirwan, G.M., J. M Barnett. e J. Minns (2001) Significant Ornitological observations from the Rio Sao Francisco Valley, Minas Gerais, Brazil, with notes on conservation and biogeography. Ararajuba 9(2): 145-161.

Laurance, W. F. \& Bierregaard-Jr., R.O. (eds.). 1997. Tropical Forest Remnants.Ecology, Management, and Conservation of Fragmented Communities.University of Chicago, Chicago, Illinois.

Lins, L.V. (2001) Diagnóstico ornitológico do Parque Estadual do. Rio Doce. Instituto Estadual de Florestas, Belo Horizonte.

Lyon, B. and K.A. Kuhnigk. 1985. Observations on nesting Ornate Hawk-Eagles in Guatemala. Wilson Bull. 97:141--147.

Machado, A.B.M., G A.B. Fonseca, R. B. Macahado, L. M. S. Aguiar e L. V. Lins. 1998. Livro vermelho das espécies ameaçadas de extinção da fauna de Minas Gerais. Belo Horizonte: FundaçãoBiodiversitas.

Madrid, J. A.; Madrid, H. D.; Funes, S. H. A.; Avila, J. A.; Botzoc, R. G. and Ramos, A. Reproductive biology and behavior Ornate Hawk-eagle in Tikal National Park, p. 92-113 In: WHITACRE, D. F; BURNHAM, W. A. and JENNY, J. P. (eds.) Maya Project: Use of raptos as environmeental indices for design and management of protect area sand for building local capacity for conservation in Latin America. The Peregrine Fund, Inc., Boise, Idaho, Progress Report 4, 1991.

Mañosa, S. and V. Pedrocchi. 1997. A raptor survey in the Brazilian Atalntic rain forest. Journal of Raptor Research 31: 203-207.

Mañosa, S.; Mateos, E.; Pedrocchi, V. and Martins, F.C. (2002). Birds of Prey Survey (Aves: Cathartiformes and Accipitriformes) in the Paranapiacaba Forest Fragment. Pp. 165-179. In: Mateos, E.; Guix, J.C.; Serra, A. and Pisciotta, K. (eds.). Censuses of Vertebrates in a Brazilian Atlantic Rainforest Area: The Paranapiacaba Fragment. Barcelona: Universitat de Barcelona.

Mañosa, S., E. Mateos, and V. Pedrocchi. 2003. Abundance of soaring raptors in the Brazilian Atlantic rainforest. Journal of Raptor Research 37:19-30.

Mendonça-Lima, A, Zilio, F., Joenck, C. M. and Barcellos, A. 2006. Novos registros de Spizaetusornatus (Accipitridae) no sul do Brasil. Revista Brasileira de Ornitologia 14 (3) 279-282 
Meunier, K. 1960. GrundsltzlicheszurPopulationsdynamik der Vogel.Z. wiss. Zool., 163 :397445.

Metzger, J.P., 2000. Tree functional group richness and landscape structure in a Brazilian tropical fragmented landscape. Ecological Applications 10, 1147- 1161.

Metzger, J.P., Martensen, A.C., Dixo, M., Bernacci, L.C., Ribeiro, M.C., Teixeira, A.M.G, Pardini, R., 2009.Time-lag in biological responses to landscape changes in a highly dynamic Atlantic forest region. Biological Conservation 142, 1166- 1177.

Mikich, S. B. e Bérnils, R. S. Livro vermelho da fauna ameaçada no Estado do Paraná. Curitiba: Instituto Ambiental do Paraná, 2004.

Montenegro, H.D.M. 1992. Behavior and breeding biology of the Ornate Hawk-Eagle.Pages 179-191 in W.A. Burnham, D.F. Whitacre, and J.P. Jenny [EDS.], Maya Project: use of raptors and other fauna as environmental indices for design and management of protected areas for building local capacity for conservation in Latin America, progress report V. The Peregrine Fund Inc., Boise, ID U.S.A.

Newton, I. 1979. Population ecology of raptors.Buteo Books, Vermillion, SD.

Oliveira-Filho, A. T. e M. A. Fontes. 2000. Patterns of floristic differentiation among Atlantic forests in southeastern Brazil and the influence of climate. Biotropica, 32: 793-810

Olmos, F., J.F. Pacheco, and L.F. Silveira. 2006. [Notes on Brazilian birds of prey]. RevistaBrasileira de Ornitologia 14:401-404.

Perry, M.Z. 2000.Factors affecting interspecies variation in home-range size of raptors. The Auk 117 (2): 511-517.

Preleuthner M., Gamauf A 1998: A possible new subspecies of the Philippine Hawk- Eagle (Spizaetusphilippensis) and its future prospect. J. Raptor Res. 32:126-135.

Prugh, L.R., Stoner,C.J., Epps, C.W, Bean, W.T., Ripple, W.J. Laliberte, A.S. e. Brashares, J.S.2009. The Rise of the Mesopredator. BioScience 59(9): 779-790.

Ranta, P., Blom, T., Niemelä, J., Joensuu, E., Siitonen, M., 1998. The fragmented Atlantic rain forest of Brazil: size, shape and distribution of forest fragments. BiodiversityandConservation 7, 385-403.

Resende, S. B. e Resende, M. 1996. Solos dos Mares de Morros: ocupação e uso. In: Alvares, V . H. V. (Org.). O solo nos grandes domínios morfoclimaticos do Brasil e o desenvolvimento sustentado. SBCS, Viçosa: 261-288.

Ribeiro, MC. et al., 2009. Brazilian Atlantic forest: how much is left and how is the remaining forest distributed? Implications for conservation. Biological Conservation, 142: 1141-1153.

Ribon, R. 1998. Fatores que influenciam a distribuição da avifauna em fragmentos de Mata Atlântica nas Montanhas de Minas Gerais. Dissertação de mestrado do Programa de Pós-Graduação em Ecologia, Conservação e Manejo da Vida Silvestre da UFMG, Belo Horizonte

Ribon, R., Simon, J.E. \& Mattos, J.E. 2003. Bird extinctions in Atlantic Forest fragments on the Viçosa region, southeastern Brazil. Conserv. Biol. 17:1827-1839.

Rizzini CT, 1979, Tratado de fitogeografia do Brasil. Aspectos sociologicos e florísticos. HUCITEC, Sao Paulo, 2: 374. 
Roda, S. A. e Pereira, G.A. 2006. Distribuição recente e conservação das aves de rapina florestais do Centro Pernambuco. Revista Brasileira de Ornitologia 14 (4) 331344.

Ryall, K.L. and L. Fahrig. 2006. Response of predators to loss and fragmentation of prey habitat: A review of theory. Ecology 87: 1086-1093.

Salvador-Jr., L.F. \& Silva, F.A. 2009. Rapinantes diurnos em uma paisagem fragmentada de Mata Atlântica no alto rio Doce, Minas Gerais, Brasil. Boletim do Museu de Biologia Mello Leitão (N. Sér.)25: 53-65.

Salvador-Jr., L.F.; Canuto, M.; Carvalho, C.E.A \&Zorzin, G. 2011. Aves, Accipitridae, Spizaetustyrannus (Wied, 1820): New records in the QuadriláteroFerrífero region, Minas Gerais, Brazil. Check List 7(1): 32-36

Sergio, F., I. Newton, and L. MarchesI. 2006. Ecologically justified charisma: preservation of top predators delivers biodiversity conservation. J. Appl. Ecol. 43:1049- 1055.

Seavy, N.E., and C.K. Apodaca. 2002. Raptor abundance and habitat use in a highlydisturbed -forest landscape in western Uganda. Journal of Raptor Research 36:5157.

Sick, H. \& Teixeira, D.M. 1979. Notas sobre aves brasileiras raras ou ameaçadas de extinção. Publ.Avuls.Mus.Nac. 62:1-39.

Sick, H. 1997. Ornitologia Brasileira, uma introdução. Nova Fronteira, Rio de Janeiro, pp. 492-503.

Silva, W.G.S., Metzger, J.P., Simões, S., Simonetti, C., 2007. Relief influence on the spatial distribution of the Atlantic Forest cover at the Ibiúna Plateau, SP. Brazilian Journal of Biology 67, 403-411.

Silveira, L. F. et al. 2009. Aves. in Bressan, P.M., M.C.M. Kierulff and A.M. Sugieda. 2009. Fauna ameaçada de extinção no Estado de São Paulo: Vertebrados. Fundação Parque Zoológico de São Paulo, Secretaria do Meio Ambiente. 645 p.

Simon et al. 2007. As aves ameaçadas de extinção no estado do Espírito Santo. In Passamani, M. e Mendes, S.L. 2007. Espécies da Fauna ameaçadas de Extinção no Estado do Espírito Santo. Instituto de Pesquisa da Mata Atlântica. Vitória.

Shultz, S. 2002. Population density, breeding chronology and diet of crowned eagles Stephanoaetuscoronatus in Ta< National Park, Ivory Coast. Ibis 144: 135-138.

Sixto, H.F. 1992. Reproductive biology, food habits, and behavior of the Black Hawk Eagle in Tikal National Park. Pages 173-178 in W.A. Burnham, D.F. Whitacre, and J.P. Jenny [EDS.], Maya Project: use of raptors and other fauna as environmental indices for design and management of protected areas for building local capacity for 67 conservation in Latin America, progress report V. The Peregrine Fund Inc., Boise, ID U.S.A.

SOS Mata Atlântica 2010.Atlas dos remanescentes florestais da mata atlântica período 20082010.

Soulé, M. E., Bolger, D. T., Alberts, A. C., Wright, J., Morice, M. and Hill, S. 1988. Reconstructed dynamics of rapid extinctions of chaparral-requiring birds in urban habitat islands. Conservation Biology 2: 75-92. 
Stotz, D. F., J. W. Fitzpatrick, T. A. Parker III, and D. K. Moskovits.1996. Neotropical birds: Ecology and conservation. University of Chicago Press, Chicago, Illinois.

Sutherland, W. J., Newton, I. \& Green, R. E. (eds). 2004. Bird Ecology and Conservation: A handbook of techniques. Oxford University Press, Oxford.

Terborgh, J. 1992. Maintenance of diversity in tropical forests.Biotropica 24(2b): $283-292$.

Thiollay, J. M. 1985. Falconiforms of tropical forests: a review. 155-165.in Newton, I. and R. D. Chancellor, editors. eds. Conservation studies on raptors. ICBP Techn. Publ. No. 5. Cambridge, U.K.

Thiollay, J.M. 1989a. Area requirements for the conservation of rain forest raptors and game birds in French Guiana. Conservation Biology 3: 128-137.

Thiollay, J.M. 1989b. Censusing of diurnal raptors in a primary rain forest: comparative methods and species detectability. Journal of Raptor Research 23: 72-84.

Thiollay, J.M. 1990. Comparative diversity of temperate and tropical forest bird communities: the intluence of habitat heterogeneity. ActaOecol. 11: 887-911.

Thiollay, J.M. 2007. Raptor communities in French Guiana: distribution, habitat selection, and conservation. Journal of Raptor Research 41:90-105.

Valverde, O. 1958. Estudo regional da Zona da Mata de Minas Gerais. Revista Brasileira de Geografia. 1: 3-82.

vanBalen, S., V. Nijman, and R. Sozer. 2001. Conservation of the endemic JavanHawk-Eagle Spizaetusbartelsi Stresemann, 1924 (Ave: Falconiformes) density, agestructureand population numbers. Contrib. Zool 70:161-173

Viana, L.C.S. 2001. Diagnóstico da cobertura vegetal do Parque Estadual do Rio Doce. Contribuição ao Plano de Manejo; Projeto Doces Matas. Instituto Estadual de Florestas (IEF).

Watson, R.T. 1998. Preface - conservation and ecology of raptors in the tropics. Journalof Raptor Research 32: 1-2

Whitacre, D. F. and C. W. Turley . 1990. Correlations of diurnal raptor abundance with habitat features in Tikal National Park. 71-92. In W.A. Burnham, D.F. Whitacre, J.P. Jenny (eds.). Maya Project, progress report III. The Peregrine Fund, Inc. Boise, Idaho.

Whitacre, D.F., Jones, L.E. and Sutter, J. 1992a. In Whitacre, D. F., and R. K. Thorstrom, (eds.). Progress report V, 1992: Maya Project, progress report V. The Peregrine Fund, Inc., Boise, Idaho.

Whitmore, T. C. 1997. Tropical forest disturbance, disappearance, and species loss, p. 3-12. In W.F. Laurance\& R. O. Bierregaard, Jr. (eds.) Tropical Forest Remnants. Ecology, Management, and Conservation of Fragmented Communities.University of Chicago, Chicago, Illinois.

Zorzin, G., Carvalho, C.E.A e Canuto, M. 2004. Dados sobre a biologia reprodutiva de Buteogallus meridionalis (Falconiformes - Accipitridae) na APA Carste de Lagoa Santa /MG. XII Congresso Brasileiro de Ornitologia - Blumenau /SC.

Zorzin, G., C.E.A. Carvalho, E.P.M de Carvalho Filho, and M. Canuto. 2006. [New records of rare and threatened Falconiformes for the state of Minas Gerais]. RevistaBrasileira de Ornitologia 14:417-421. 
Zorzin, G. (2011). Os efeitos da fragmentação da Mata Atlântica sobre a riqueza e abundância de Accipitriformes e Falconiformes na Zona da Mata de Minas Gerais. Dissertação de Mestrado. Viçosa: Programa de Mestrado em Biologia Animal Universidade Federal de Viçosa. 


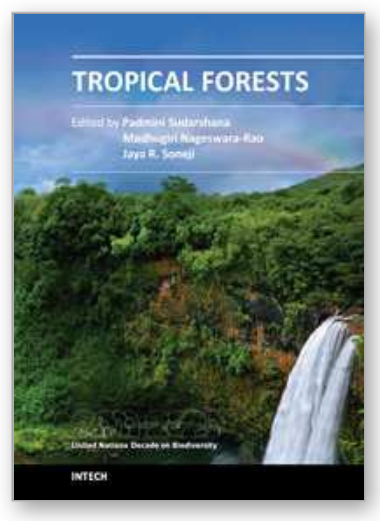

\section{Tropical Forests}

Edited by Dr. Padmini Sudarshana

ISBN 978-953-51-0255-7

Hard cover, 388 pages

Publisher InTech

Published online 14, March, 2012

Published in print edition March, 2012

The astounding richness and biodiversity of tropical forests is rapidly dwindling. This has severely altered the vital biogeochemical cycles of carbon, phosphorus, nitrogen etc. and has led to the change in global climate and pristine natural ecosystems. In this elegant book, we have defined "Tropical Forests" broadly, into five different themes: (1) tropical forest structure, synergy, synthesis, (2) tropical forest fragmentation, (3) impact of anthropogenic pressure, (4) Geographic Information System and remote sensing, and (5) tropical forest protection and process. The cutting-edge synthesis, detailed current reviews, several original data-rich case studies, recent experiments/experiences from leading scientists across the world are presented as unique chapters. Though, the chapters differ noticeably in the geographic focus, diverse ecosystems, time and approach, they share these five important themes and help in understanding, educating, and creating awareness on the role of "Tropical Forests" for the very survival of mankind, climate change, and the diversity of biota across the globe. This book will be of great use to the students, scientists, ecologists, population and conservation biologists, and forest managers across the globe.

\section{How to reference}

In order to correctly reference this scholarly work, feel free to copy and paste the following:

M. Canuto, G. Zorzin, E.P.M. Carvalho-Filho, C.E.A. Carvalho, G.D.M. Carvalho and C.E.R.T Benfica (2012). Conservation, Management and Expansion of Protected and Non-Protected Tropical Forest Remnants Through Population Density Estimation, Ecology and Natural History of Top Predators; Case Studies of Birds of Prey (Spizaetus taxon), Tropical Forests, Dr. Padmini Sudarshana (Ed.), ISBN: 978-953-51-0255-7, InTech, Available from: http://www.intechopen.com/books/tropical-forests/conservation-management-and-ampliationof-protected-and-non-protected-tropical-forest-remnants-throu

\section{INTECH}

open science | open minds

\author{
InTech Europe \\ University Campus STeP Ri \\ Slavka Krautzeka 83/A \\ 51000 Rijeka, Croatia \\ Phone: +385 (51) 770447 \\ Fax: +385 (51) 686166 \\ www.intechopen.com
}

\author{
InTech China \\ Unit 405, Office Block, Hotel Equatorial Shanghai \\ No.65, Yan An Road (West), Shanghai, 200040, China \\ 中国上海市延安西路65号上海国际贵都大饭店办公楼 405 单元 \\ Phone: +86-21-62489820 \\ Fax: +86-21-62489821
}


(C) 2012 The Author(s). Licensee IntechOpen. This is an open access article distributed under the terms of the Creative Commons Attribution 3.0 License, which permits unrestricted use, distribution, and reproduction in any medium, provided the original work is properly cited. 